\title{
КРЕСТЬЯНСКИЕ ПЕРЕСЕЛЕНИЯ В 1920-Е ГОДЫ (ИЗ ИСТОРИИ МИГРАЦИИ В РОССИИ)
}

\author{
ВАЛЕНТИНА МОИСЕЕНКО
}

\begin{abstract}
Трансформация миграции после октября 1917 г., неизбежная в силу коренного переустройства политической и сочиально-экономической системы общества, означала изменение характеристик основных ее видов. Теоретические основы трансформации миграции были заложены в годы военного коммунизма и востребованы в конце 1920-х годов.

В силу объективных и субъективных причин трансформация не могла не затронуть миграцию крестьян в многоземельные районы, которая была тесно связана с довоенным этапом переселения $и$ колонизации и оставалась в 1920-е годы одной из иентральных проблем. В характерных чертах регулирования этих процессов (позднем открытии планового переселения в 1924-1925 г2. и закрытии переселения индивидуальных крестьянских хозяйств в 1930 г., «отмене» термина «колонизация») проявилось отношение к прочессам, сыгравших большую роль в истории России. Но короткому времени, отведенному переселению и колонизации в 1920-е годы, предшествовал период, насыщенный маситабным движением крестьян в Азиатскую Россию, обсуждением перспектив этого процесса. Поэтому в 1920-е годы невозможно было не учитывать довоенные тенденции и последствия переселения, большой опьт переселенческого дела - информационный, законодательный $u$ организационный. «Проводниками» такого опыта были ученые и специиалисты. Часть из них работала в бывшем Переселенческом управлении. Однако попытка «возрождения» переселения противоречила планам государства. В конце 1920-х годов состояние переселения оценивалось как кризисное. Одновременно были прекращены исследования колонизации и переселения.
\end{abstract}

Фактически переселение крестьян с 1880-х до конща 1920-х годов было единым процессом. Это обстоятельство определило структуру статьи. При этом наименее изученным является последний этап - переселение в 1920-е годы.

Ключевые слова: трансформация миграции, переселение, аграрное перенаселение, колонизация, переселенческое дело, переселенческая статистика, состав переселенцев, плановое переселение, районы выхода и вселения, переселенческая политика, эффективность переселения, Россия.

Револючия отмела ...все переселенческое дело...с его аграрно-помещичьей колонизаторской идеологией. На смену возрождается новое, советское переселение, построенное на совершенно иной экономической и сочиально-политической основе.

[Переселенческое дело 1927: 3]

\section{ИЗ ОПЫТА ПЕРЕСЕЛЕНИЯ И КОЛОНИЗАЦИИ В ДОРЕВОЛЮЦИОННОЙ РОССИИ. НОВЫЙ КУРС НА РУБЕЖЕ 1910-Х ГОДОВ}

В обширной дореволюционной историографии переселение крестьян определяется как одно из существенных и устойчивых явлений русского народного быта, тесно связанное с положением крестьян во «внутренних» (европейских) губерниях, расширением границ государства, политикой заселения окраин.

ВАЛЕНТИНА МИХАЙЛОВНА МОИСЕЕНКО. МОСКОВСКИЙ ГОСУДАРСТВЕННЫЙ УНИВЕРСИТЕТ ИМЕНИ М.В. ЛомоносовА, РОсСия. E-mail: VMOISEENKO.MSU@MAIL.RU.

СТАТЬЯ ПОСТУПИЛА В РЕДАКЦИЮ В МАРТЕ 2015 Г. 
Значительный рост масштабов переселения крестьян в Сибирь, начавшийся с 1880х годов, был вызван последствиями реформы 1861 г., малолоземельем и кризисным состоянием крестьянского хозяйства, быстрым увеличением численности сельского населения в Европейской России (В.И. Чаславский, Ю.Э. Янсон, В.Н. Григорьев, И.А. Гурвич, А.А. Исаев, Ф. Воропонов, А.А. Кауфман и др.). Хотя интенсификация декларировалась как магистральное развитие земледелия, но из-за недостатка средств и знаний для интенсификации крестьяне выбирали переселение. Рост внимания к заселению Сибири стимулировала территориальная близость огромного Китая, а также поражение России в Русско-Японской войне (1904-1905 гг.) [Ядринцев 1892: 212].

Увеличение масштабов и большие трудности переселения за Урал, общественный интерес к движению крестьян способствовали пересмотру позиции правительства, «игнорировавшего переселения при проведении реформы 1861 года» (Ю.Э. Янсон). Переселенческая политика государства была реализована в положениях и законах 1881, 1889, 1904 и 1906 гг. В 1897 г. был создано Переселенческое управление МВД, переданное в 1906 г. в Главное управление землеустройства и земледелия. В рамках Государственной Думы III созыва (1907 г.) работала Особая комиссия по переселенческому делу. В начале XX века переселение крестьян в Азиатскую Россию преобразилось «из едва ли не ведомственного мероприятия в важнейшее дело с грандиозными задачами и вновь открывавшимися горизонтами в будущем» [Вощинин 1912: 1-2].

Ключевыми вопросами переселенческой политики в довоенное время были масштабы и эффективность переселения, состав переселенцев. По данным переселенческой статистики, результаты перемещения за Урал в 1885-1913 гг. оцениваются в размере 5159 тыс. семейных переселенцев и ходоков. Число обратных (семейных) переселенцев составило 517 тыс. (14\%). Ежегодный максимум первой волны переселения (82-84 тыс. человек) пришелся на «голодные» 1891-1892 гг., второй (200-219 тыс.) - на 1898-1900 гг., третьей (744-682 тыс.) - на 1908-1909 гг. [Кауфман 1915b: 2-3]. Динамика переселения свидетельствует о постепенном росте масштабов при его существенных колебаниях в отдельные годы. Наибольшая его величина пришлась на время проведения аграрной реформы П.А. Столыпина.

За этот период движение «пионеров», «первопроходцев», крестьян средней состоятельности сменилось переселением малоземельных и безземельных семей, вызванным ухудшением положения крестьян после реформы 1861 г. Удельный вес безземельных переселенцев вырос с 15,3\% в 1894-1899 гг. и 20,0\% в 1903-1906 гг. до 24,5\% в 1907-1911 гг. [Огановский 1914: 94]. Демографическую структуру переселенцев определяли большие семьи, в составе которых было несколько мужчин-работников. Основные места выхода охватывали аграрно-перенаселенные черноземные губернии Европейской России (Полтавскую, Курскую, Черниговскую, Воронежскую, Могилевскую, Харьковскую, Киевскую, Орловскую, Самарскую, Витебскую, Екатеринославскую и др.) с высокой плотностью сельского населения и низкими земельными наделами [Ямзин 1912: $15-16]$. 
На протяжении довоенного периода высоким оставался удельный вес самовольных переселенцев. Поэтому период с 1880-х годов до начала Первой мировой войны определяется как «история самовольных переселений» [Ленский 1914: 96].

До 1906 г. «самовольцами» считались семьи, переселявшиеся без специального разрешения - проходного свидетельства. Формально потребность в термине «самовольное переселение» отпала после 1906 г. Однако масштабы самовольного движения (по паспортам) оставались значительными, хотя по терминологии начала $\mathrm{XX}$ века «нелегальные» (самовольные) переселенцы не имели права на льготный проезд по железной дороге, им не предоставлялись в первую очередь земельные участки и т.д.

В 1896-1911 гг. движение самовольцев в Азиатскую Россию составило 2/3 легального переселения. Особенно значительным был приток этой категории в Томскую губернию и Акмолинскую область. Три переписи, проведенные в Томской губернии в 1899 1911 гг., выявили значительные масштабы «непричисленных самовольцев» (в 1909 г. их число составило 80746 семей, всего 454144 человек) и тяжелое положение этой группы. $40 \%$ «неприписанных» семей не имели необходимого хозяйства - жилища, пашни, скота. [Огановский 1914: 127-128].

Существенные показатели самовольного движения отразили большие трудности регулирования переселения в условиях определяющего влияния «выталкивающих» факторов в местах выхода крестьян, низкого уровня образования переселенцев, слухов и писем родственников как главных источников информации о районах вселения.

Усиление роли государства в регулировании переселения означало рост государственных расходов. Их величина, составлявшая 3-4 млн руб. ежегодно в период деятельности Сибирского комитета, поднялась до 5,6 млн руб. в 1906 г. и 30 млн руб. в 1914 г. [Кауфман 1915a: 538].

В целом в предвоенные годы переселение в Азиатскую Россию было свободным. Государство регулировало его в виде помощи при ликвидации земельных наделов, признании обязательным ходачества, поддержки переселения земствами ряда губерний Европейской России и др. Весь переселенческий процесс находился в ведении единой организации, образовывавшей переселенческие участки, выдававшей ссуды и оказывавшей сельскохозяйственную, медицинскую, агрономическую помощь и т.д. Передвижение обслуживали специальные поезда. Была налажена относительно полная регистрация переселенцев, ходоков и обратников. Но, начиная с 1889 г., за исключением отдельных лет, хроническим было несоответствие между потребностью крестьян в переселении и наличием земельных участков, подготовленных для заселения. Значительным было обратное движение. На наш взгляд, такое положение согласуется с громадным значением переселенческого дела и громадной трудностью его организации [Белевский 1904: 1].

Важным стало подведение итогов переселения. Их анализ учитывал сравнительное изменение положения хозяйства переселенческой семьи в районах вселения и в районах выхода. В то же время, под влиянием индустриализации страны, роста отхода крестьян на заработки, увеличения численности городского и сельского населения, новых задач в 
заселении Дальнего Востока формировался широкий взгляд на функции и последствия переселения.

В начале 1900-х годов был пересмотрен взгляд на роль переселения в решении ключевой проблемы - аграрного перенаселения: его значение было признано ограниченным, поскольку масштабы не поглощали возраставшей величины естественного прироста сельского населения в Европейской России. Противоречивыми оказались сведения об уровне социально-экономического положения переселенцев в различных зонах заселяемых районов. В местах вселения скапливалось большое число неустроенных переселенцев. Нарастали противоречия между интересами губерний выхода и вселения. Усложнялись отношения переселенцев и сибирских старожилов, коренных жителей Степного края и Туркестана. Согласование таких интересов, прежде всего мест выхода и вселения, справедливо считалось более сложной задачей по сравнению с регулированием интересов стран эмиграции и иммиграции [Беркенгейм 1902: 1-3]. Наконец, переселение не смогло, как ранее предполагалось (А.И. Васильчиков и др.), предотвратить массовую эмиграцию из России, охватившую в 1880-е годы юго-западные районы Европейской России. Однако подведение итогов переселения сдерживала неразработанная методология их расчета. Только во второй половине 1920-х годов началось обсуждение этой задачи. При этом отмечались значительные возможности ее решения, учитывая открытые данные бюджета бывшего Переселенческого управления. Однако и в настоящее время подобная работа не выполнена. Поэтому были подведены по существу предварительные итоги переселения.

По расчетам Переселенческого управления, сообщенным Г.Ф. Чиркиным осенью 1917 г. ${ }^{1}$, ежегодное в течение предвоенного десятилетия переселение, в среднем, около 60 тыс. семей за Урал требовало 25 млн руб., не учитывая денежных, трудовых и других затрат самих переселенцев. В то же время оброчная подать в Сибири за 1906 - 1913 гг. увеличилась с 6 до 13 млн руб. Посевная площадь в Азиатской России в 1908-1914 гг. росла ежегодно почти на 1 млн десятин (в Западной Сибири - на 50\%). Экспорт сибирского масла в 1913 г. достиг 5 млн пудов стоимостью 75 млн руб. Сибирская железная дорога в 1913 г. получила 13,5 млн руб. чистого дохода. Кроме того, в результате роста потребностей населения увеличился сбор косвенных налогов [Журнал... 1917a: 137-138].

Благодаря притоку переселенцев городское и сельское население Сибири росло быстрее, чем в Европейской России. В 1897 г. население 12 губерний и областей Сибири составляло 8184,4 тыс. человек. В 1917 г. оно достигло 14440,1 тыс. Ежегодный прирост сибирского населения $(3,8 \%)$ был почти в 3 раза выше аналогичного показателя по Европейской России (1,3\%). Городское население Сибири росло в 1,5 раза быстрее, чем в Европейской России (соответственно 6 и 4\%) [Огановский 1921: 35-36].

Перепись 1926 г. подтвердила большую роль притока населения в Азиатскую часть СССР. Чистая миграция населения, т.е. разница между числом уроженцев других территорий СССР, прибывших в районы Азиатской части СССР, и числом уроженцев этих

1 В рассматриваемое время Г.Ф. Чиркин - начальник Переселенческого управления Министерства земледелия. 
районов, зарегистрированных в других частях СССР, составила в РСФСР 1125,4 тыс., в том числе в Казахской АССР - 638,7 тыс., в Киргизской АССР - 68,1 тыс., Сибирском крае 1986,5 тыс., Дальневосточном - 337,5 тыс. человек. Положительный прирост населения за счет миграции был зарегистрирован в Узбекской ССР (196,3 тыс. человек) и Туркменской CCP (62,8 тыс.) [Всесоюзная перепись... 1931: 174-175, Табл. V].

Положительные результаты переселения были учтены при обсуждении перспектив развития Азиатской России. В речи на заседании Государственной Думы 16 марта 1910 г. министр Главного управления землеустройства и земледелия А.В. Кривошеин, говоря о переселенческой политике в Азиатской России в предшествующие годы, определил ее как самодовлеющую государственную задачу. В противовес такой задаче была выдвинута идея широкой колонизации Азиатской России с участием государства [Симонов 1917: 16].

В рамках нового подхода центр тяжести предлагалось сместить с масштабов переселения на качество обустройства переселенцев. Переселение должно было приобрести чрезвычайно многосторонний характер. Для этого необходимо было преодолеть колебание взглядов на переселение в Сибирь, выполнить в этом регионе комплекс агрокультурных, экономических и технических мероприятий по мелиорации земель, строительству дорожной сети, преодолеть кризис экстенсивных форм ведения сельского хозяйства и др. [Огановский 1914: 304-311, 313, 317]. Обсуждавшаяся концепция колонизации Сибири исходила из развития России по западноевропейскому пути, т.е. преодоления тяжелых последствий аграрного перенаселения $\mathrm{c}$ помощью индустриализации, хотя и медленной. Поэтому декларация правительством «новой стратегии политики в Азиатской России» подтвердила отказ от решения аграрного вопроса в Европейской России с помощью переселения крестьян за Урал. Как средство решения более широкого круга задач колонизация Азиатской России рассматривалась с позиций подъема производительных сил страны [Огановский 1914: 247]. В то же время ошибочным и даже самоубийственным считалось представление о колонизации, не учитывавшее интересы «метрополии» - страны с избыточным земледельческим населением. Поскольку индустриальный (городской) сектор экономики мог поглотить естественный прирост лишь частично, переселение избыточного населения в Азиатскую Россию предлагалось рассматривать в качестве «второго по величине фактора выхода избыточного сельского населения». Переселение так называемыми «гнездами», т.е. из отдельных губерний и уездов, позволяло расселить часть избыточного земледельческого населения не только в Европейской России, но и на свободных землях за Уралом, не пренебрегая переселением как одним из элементов аграрной политики [Огановский 1914: 61, 306].

Сохраняя переселение, предполагалось одновременно решить другую задачу защитить земельные интересы старожилов и туземного населения.

Остроту такой задачи подтверждают статистические данные. За 1905-1916 гг. численность крестьян в Степном крае выросла с 427 до 1221 тыс., казаков - с 246 до 327 
тыс., киргизов - с 2047 до 2179 тыс. ${ }^{2}$ В 1905-1916 гг. рост русского населения был отмечен в Омском (900\%), Кокчетавском (160\%), Петропавловском (156\%), Кустанайском (131\%), Актюбинском (890\%) уездах. Быстро также росло русское население во всех уездах Семипалатинской области и в ряде уездов Уральской области. Обратное движение за 18961916 гг. составило 12\% [Тресвятский 1917: 35-40, 43].

Противоречивые последствия переселения в Степной край и в другие районы не оставались без внимания - в довоенное время землеустройство коренных жителей (киргизов) было признано одним из важных вопросов переселения. Но стихийный приток переселенцев после окончания Русско-Японской войны отодвинул решение «киргизского вопроса» на второй план. В рамках земельной реформы, обсуждавшейся летом и осенью 1917 г., вопрос землеустройства коренных жителей «должен был получить окончательное решение» [Тресвятский 1917: 61-62].

При обсуждении земельных отношений, сложившихся в Степном крае, учитывались итоги работы двух экспедиций: под руководством Ф.А. Щербины (1896-1900 гг.) и В.К. Кузнецова (1907-1911 гг.). Не вдаваясь в подробности организации работы этих экспедиций, отметим, что итоги их работы оценивались с позиций защиты земельных интересов коренного населения [Седельников 1907: 73-74].

Согласно одной из оценок, опубликованной в советские годы, заслуга Ф.А. Щербины при установлении норм землепользования заключалась в том, что экспедиция крайне осторожно и внимательно отнеслась к киргизскому хозяйству, и, руководствуясь тем, что хозяйственные особенности края мало изучены и им можно дать лишь общую характеристику, нормы были рассчитаны со значительными прибавками против установленных средних арифметических хозяйств по каждому уезду [Кенарский 1924: 122]. В то же время реальное землепользование находилось под влиянием притока переселенцев в Тургайскую, Уральскую, Акмолинскую, Семипалатинскую и Семиреченскую губернии и области. Жалобы местного населения на постановления временных комиссий о землеустройстве «систематически отклонялись областным правлением» [Кенарский 1924: 124]. Положение усложнилось после реорганизации Переселенческого управления и подъема переселенческого движения в 1906 г.

В результате повторного статистико-экономического обследования в 1907-1911 гг. (под руководством В.К. Кузнецова) нормы землепользования киргизов были уменьшены и установлены новые «излишки» земли. За 1906-1915 гг. переселенческих участков было заготовлено в 2 раза больше по сравнению с 13-летним периодом до 1906 г. Сам процесс образования переселенческих участков сопровождался нарушениями [Кенарский 1924: 132- 133].

Как видим, начиная с 1880-х годов в переселенческом движении происходили количественные и качественные изменения, был накоплен большой опыт его регулирования. В то же время на рубеже 1910-х годов очевидной стала необходимость

\footnotetext{
${ }^{2}$ Границы Степного края (Степного генерал-губернаторства, 1882-1917 гг.) со временем менялись. В данном случае Степной край рассматривается в составе Акмолинской, Семипалатинской, Тургайской и Уральской областей.
} 
повышения социально-экономической эффективности переселения, означавшая уточнение его функций и последствий, связанных с колонизацией заселяемых территорий. «Самодовлеющая» сила переселения должна была проявиться в росте производительных сил заселяемых территорий, урегулировании отношений переселенцев и жителей районов заселения. Задача следующего этапа состояла в применении опыта с учетом изменившихся общественно-политических условий.

\section{ПЕРЕСЕЛЕНИЯ КАК ЧАСТЬ АГРАРНОЙ РЕФОРМЫ В 1917 Г .}

Переселение за Урал во время Первой мировой войны в основном прекратилось. В 1915 г. в Сибири водворилось 220 тыс. переселенцев: часть по довоенному зачислению, часть - «по паспортам». В решениях Временного правительства ставилась задача исправить недостатки в организации переселения, накопившиеся в предыдущие годы [Ямзин, Вощинин 1926: 68, 70].

Огромный интерес к реформированию земельных отношений после февраля 1917 г. стимулировал обсуждение перспектив колонизации и переселения в России, которое происходило в течение весны-осени 1917 г. на заседаниях Лиги аграрных реформ и Комиссии по вопросам переселения и колонизации, созданных Главным земельным комитетом для подготовки материалов к Учредительному собранию.

Позиция многих ученых и работников Переселенческого управления, расходившаяся в частностях, была единой в признании необходимости продолжения политики переселения за Урал. По одному из вариантов плана земельной реформы только на втором ее этапе (т.е. не менее чем через два десятилетия), после землеустройства местного населения, предлагалось расселение малоземельного крестьянства из густонаселенных районов на запасных землях государственного фонда [Огановский 1917: 11]. События ближайших не соответствовали этому предложению.

Обсуждая перспективы переселения, Комиссия по вопросам переселения и колонизации (август - сентябрь 1917 г.), как и в довоенное время, учитывала необходимость решения стратегической задачи - колонизации Сибири, исходя из возраставших возможностей государства ${ }^{3}$. Правда, из-за непредсказуемой общественно-политической ситуации, сложившейся осенью 1917 г., на данном этапе речь могла идти только о некоторых принципах концепции, а не о ее содержании.

Перспективы политики переселения и колонизации обосновывались тесными взаимосвязями развития Сибири и подъема производительных сил страны. Новые земельные отношения означали необходимость реформирования переселенческого дела, в рамках которого предстояло определить роль переселения в поглощении избыточного земледельческого населения Европейской России и сокращении малоземелья [Журнал комиссии... 1917a: 140-141]. Политика колонизации Сибири должна была также учесть

${ }^{3}$ В обсуждении перспектив переселения и колонизации в августе-сентябре 1917 г. приняли участие работники Переселенческого управления Министерства земледелия, а также ученые: А.А. Кауфман, Г.Ф. Чиркин, А.Н. Челинцев, П.И. Попов, В.П. Вощинин, В. А. Тресвятский, А.А. Чарушин, А.А. Татищев и др. 
почти полную исчерпанность «легких» для заселения земель, необходимость крупных капиталовложений в дорожное строительство, мелиоративные и осушительные работы, культурные объекты и т.д. В то же время переход к трудноосваиваемым землям требовал от будущих переселенцев (колонистов) большей выносливости, энергии, знаний. Примером служили американские государства, имевшие образцовые колонии и производившие тщательный отбор переселенцев - участки земли предоставлялись лицам, крепким не только в материальном, но и культурном отношении. В дореволюционной России, как отмечалось, главным контингентом переселенцев было полупролетаризированное крестьянство и частично - сельскохозяйственный пролетариат. Переселенцы в России были не только имущественно не обеспечены, но и малокультурны [Журнал... 1917а: 145-146, 150]. Учитывая социально-экономические условия в России в 1920-е годы, возможности изменения состава переселенцев «по американскому образцу» не были реалистичными.

Наиболее перспективной была признана «государственная», «планомерная» колонизация. Лишь немногие, в их числе и А.А. Кауфман, предлагали другой путь - не «регламентированных переселений, а естественного роста и размещения населения в связи “с общим развитием края"».

При обсуждении вопроса о согласовании интересов «метрополии» и «колоний» вызвал сомнение вывод о главенстве интересов «метрополии», доминировавший, как отмечалось, в довоенный период. Реализация принципа самоуправления означала определение бывшими «колониями» емкости собственной территории, порядка ее заселения и т.д. В то же время небезосновательным было утверждение о предсказуемой позиции органов местного самоуправления, учитывавших в первую очередь интересы местного населения. Поэтому предлагалось сосредоточить колонизационный земельный фонд в распоряжении государства [Журнал... 1917a: 162, 164]. Опыт организации переселения в 1920-е годы подтвердил выводы об изменении характера взаимоотношений «метрополии» и «окраин» и большой роли государственного колонизационного фонда в решении земельного вопроса.

В итоге Комиссия по вопросам переселения и колонизации выработала следующие принципы колонизации России.

1. Содействуя более равномерному распределению населения по территории страны, более производительному использованию его труда, развитию промышленности и земледелия, увеличению в конечном итоге народного благосостояния, переселение и колонизация признавались делом особой государственной важности. В противовес стихийному переселению крестьян «планомерная колонизация» Азиатской России означала количественное и качественное развитие производительных сил колонизуемой территории, осуществляемой государством.

2. Колонизация, осуществляемая государственной властью в лице центральных и местных органов, предполагала свободную доступность колонизуемой территории для всех граждан, согласование интересов общегосударственных и местного населения в целях культурного и экономического подъема всей страны и местного населения. 
3. Всесторонность колонизации означала не только земледельческое, но и промышленное освоение заселяемой территории, а ее последовательность - всесторонний учет особенностей колонизуемого района.

4. Особо отмечалось общегосударственное начало в деле колонизации: в определении правительством основных колонизационных мероприятий - подготовке колонизационного фонда с помощью строительства железных дорог, оросительных систем, промышленных предприятий и т.д. [Журнал... 1917b: 164-167].

Как видим, в феврале-сентябре 1917 г. обсуждение вопросов переселения и колонизации находилось в русле довоенных разработок. В то же время учитывалась возросшая роль политического фактора: провозглашения независимости ряда территорий и возросших прав коренного населения на землю заселявшихся районов. В связи с этим в 1918 г. были ограничены переселения в Сибирь, Степной край (т.е. в Киргизскую Республику, вошедшую в 1920 г. в состав Российской Федерации), в Туркестан и Закавказье. В этих районах после Февральской революции на фоне ослабления авторитета центральной власти, усиления сепаратистского движения обострились отношения между переселенцами и местным населением. Поэтому потенциал колонизационных районов в новых общественно-политических условиях оценивался как незначительный. Перспективой для переселения считалась только лесостепная полоса Сибири, т.е. район расселения сибирских старожилов и сосредоточения сибирской колонизации. Но и в этот район приток переселенцев считался возможным только после земельного устройства местного населения. Местные власти старались сдерживать переселение «с максимальной широтой», поскольку сибирские старожилы, «стиснув зубы, скрепя сердце, мирились во времена самодержавия» с получением земли значительно меньше, чем переселенцы, и теряли в пользу переселенцев «весьма необходимые угодья» [Кауфман 1918: 8-9].

Перспективы переселения в Степной край оценивались как более сложные. После февраля 1917 г. усилилась критика земельной политики царского правительства, поскольку нарушалось необходимое условие нормального заселения - первоначальное землеустройство коренного населения. Положение в Туркестане, рассматривавшемся до войны как область русской колонизации, осложнялось тем, что проведение здесь земельной реформы означало распределение воды среди довольно многочисленного контингента кочевого населения, имевшего низкую обеспеченность землей в ряде районов. При этом неизменным признавалось первостепенное значение хлопководства в экономике страны [Кауфман 1918: 22, 25].

В итоге переселенческий потенциал основных колонизационных районов на ближайшие годы оценивался пессимистически. Предвидение А.А. Кауфмана и других специалистов о необходимости проведения осторожной переселенческой политики на окраинах страны подтвердила практика 1920-х годов.

Резервом для переселений из малоземельных губерний считались отчуждаемые земли в юго-восточных губерниях Европейской России. Но и здесь серьезное противодействие переселению требовало предварительного его согласования с интересами местного населения, которое оценивалось как «бесконечно трудная задача». 
Как видим, подходы к переселению и колонизации в 1917 г. учитывали довоенный опыт - необходимость свободы переселения и обеспечения равного права за землю различных групп населения, согласования интересов местного и пришлого населения, региональных и государственных и т.д. Критика политики государства на заселяемых территориях, особенно в Степном крае и Туркестане, начавшаяся в довоенное время, продолжилась в период Временного правительства. В то же время вопросы переселения и колонизации не снимались с повестки дня - они отвечали потребностям развития производительных сил страны. Опыт 1920-х годов подтвердил актуальность многих положений, выработанных летом-осенью 1917 г.

\section{ПЕРЕСЕЛЕНИЯ В 1918-1921 ГГ.}

Известно, что концепция военного коммунизма отрицала свободное перемещение населения в пределах РСФСР и за ее границы. Закон «О социализации земли» [СУ РСФСР 1918] не предусматривал переселение в пределах Европейской России или в Азиатскую Россию. Землеустройство, связанное с реализацией этого закона, было ограничено расселением малоземельных крестьян в другом поясе губернии. Это означало преобладание внутригубернского расселения, особенно внутриуездного и даже внутриволостного местные жители быстрее реагировали на изменения в земельных отношениях. Переселение из других губерний на земли колонизационного фонда в пределах республики сдерживали многочисленные трудности.

По этой причине, например, масштабы расселения в Одесской губернии в 1922-1924 гг. превысили число переселившихся из лесостепных губерний на колонизационные фонды Украины [Серяков 1924: 27]. Учитывая недостаток средств для их освоения, VIII Всеукраинский съезд Советов разрешил переселяться только «хозяйственно устойчивым крестьянским дворам», способным устроиться в местах водворения за свой счет [Постановление 1924: 51]. Но и в этом случае переселиться на земли колонизационного фонда могли только граждане УССР [Проект правил... 1924: 114].

Современники обратили внимание на своеобразную «национализацию» государством переселенческого дела в законе «О социализации земли»: все бремя регулирования переселения возлагалось на государство, оставляя переселяющимся только выполнение плана [Ямзин, Вощинин 1926: 72].

В то же время вопросы переселения оставались на повестке дня.

На II Всероссийском землеустроительном съезде (январь 1921 г.) были выработаны новые подходы к переселению и переселенческой политике. Характер переселения при социализме был определен как противоположный таковому при капитализме. Это означало, что на смену «полной свободе хозяйственных передвижек», свойственных капиталистическому строю, в социалистическом государстве должно было придти переселение, подчиненное единому плану. Неорганизованные переселения (так называемые самотечные) были признаны «неприемлемыми, как исходящие из антигосударственной трактовки вопроса». Переселение, отвечающее конечной цели аграрного строительства при социализме, должно было соответствовать двум условиям: 
1) наличию излишков рабочей силы в одной местности; 2) наличию подготовленных для заселения свободных земель в другой. До конкретного определения таких условий массовые перемещения на свободные земли прежнего, т.е. довоенного, заселения признавались, как правило, недопустимыми [Ямзин, Вощинин 1926: 76].

Однако хозяйственная разруха, нарушенные связи между потребляющими и производящими районами, ликвидация промыслов, падение промышленного производства, голод, обострение межнациональных отношений и другие причины вызывали переселения в отдельных районах в течение 1918-1921 гг. Особое внимание привлекало положение на окраинах страны - в районах довоенного заселения.

Во второй половине 1917 г. началось движение семей демобилизовавшихся за Урал. В начале 1918 г. оно охватило семьи рабочих закрывшихся предприятий. За первую половину 1918 г. за Урал переселилось около 100 тыс. человек. Но учет последующего передвижения стал невозможным из-за мятежа чехословаков и реорганизации Переселенческого управления [Вощинин 1921: 132].

В течение первой половины 1921 г. в Туркестане 4 было ликвидировано около 6000 русских и меннонитских хозяйств с населением 30 тыс. человек. Во второй половине 1921 г. ликвидация переселенческих хозяйств была продолжена. Аналогичным было положение в Киргизской Республике 5 . Деколонизация в насильственной форме произошла в Горской республике на Северном Кавказе, где в свое время русское население потеснило местное население в горы. Из Северо-Двинской губернии эстонские переселенцы возвратились в независимую Эстонию. Деколонизация Сибири проявилась в обратном движении украинцев, стремившихся принять участие в дележе «панских земель», а также в переселении из таежных районов, лишившихся подвоза хлеба из южных районов и возможности заниматься промыслами, на юг Сибири - в Минусинские, Алтайские и Славгородские земли. По данным сибирских земельных органов, таежные волости Мариинского уезда Томской губернии потеряли около 40\% своего населения, а некоторые села выселились целиком. Государство пыталось использовать переселение в политических целях. В 1919 г. «в срочном порядке» было объявлено переселение рабочих и крестьян из северных губерний в Воронежскую, Тамбовскую и другие губернии и в Донскую область для «облегчения тяжелого продовольственного положения» [CУ РСФСР 1919]. Современники увидели в действиях власти стремление нейтрализовать ненадежные районы, заселенные казаками. Всего было переселено около 8000 человек, перевезенных в

\footnotetext{
${ }^{4}$ Имеется в виду существовавшая в 1918-1924 гг. в составе РСФСР Туркменская АССР со столицей в Ташкенте. В конце 1924 г. на ее территориях были созданы Узбекская, Таджикская и Туркменская республики.

${ }^{5}$ Киргизская АССР со столицей в Оренбурге была образована в составе РСФСР в 1920 г. из ряда областей, населенных в основном казахами. Впоследствии ее границы неоднократно изменялись. В 1925 г. была переименована в Казакскую АССР со столицей в Кзыл-Орде, а с 1927 г. - в Алма-Ате. В 1936 г. преобразована в Казахскую ССР. Киргизской АССР с 1926 г. стала называться существовавшая до этого в составе РСФСР, а еще раньше - в составе Туркменской АССР Кара-Киргизская автономная область с центром в Пишпеке (впоследствии Фрунзе, а затем Бишкек). В 1936 г. она также стала союзной республикой СССР - Киргизской ССР. С конца 1991 г. - независимые государства Казахстан и Киргизия.
} 
9 эшелонах [Большаков 1923: 484-485]. Заметим, что неподготовленное переселение происходило в районы со сложными и неурегулированными земельными отношениями.

В тяжелом положении оказались казаки, переселенные в 1920 г. в Терскую губернию из Закавказья, Ганджи и других мест, - всего около 5000 семей, обвиненных «в сношении с контрреволюционными бандами» [Сельскохозяйственная жизнь 1921].

Неурожай в 1920 и 1921 г. открыл массовые «голодные переселения».

Крестьяне «голодных губерний» потребовали разрешить им переселяться. В 1920 г. «голодное переселение», охватившее 7 губерний, составило 208310 человек. По требованию Киргизской Автономной Республики и вследствие хорошего урожая в ряде губерний переселение было уменьшено на 125 тыс. человек [Вощинин 1921: 136].

Голодное переселение 1921 г., еще более масштабное и стихийное по сравнению с 1920 г., охватило 12 губерний только в Поволжье [СУ РСФСР 1921]. В голодающих губерниях разрешение на переселение получили те, у кого было «нарушено хозяйство» и кто мог подтвердить наличие личных или хозяйственных связей с благополучными по урожаю местностями. Из пострадавших от голода губерний (Астраханской, Царицынской, Саратовской), Татарской Республики, Чувашской и Марийской областей и Вятской губернии было разрешено выселить не более 105 тыс. человек. Однако число зарегистрированных переселенцев достигло 540 тыс., фактически их было свыше 1 млн [Ямзин, Вощинин 1926: 79].

Сложным, по сообщениям местных властей, было положение в районах заселения, в первую очередь в Сибири, где находилось большое число «неприписных» переселенцев, пришедших «самотеком» в разное время и претендовавших на обеспечение землей.

Опыт организации переселения в 1920 г. показал необходимость учета интересов автономных республик, «не только не приемлющих к себе русских переселенцев, но и принудительно выдворяющих таковых из своих пределов (Туркестан и Киркрай) единственно по признаку национальности». Здесь едва ли не в первых постановлениях декларировалась закрытость от каких бы то ни было переселенческих вторжений извне [Вощинин 1921: 135-136].

Как видим, постоянно возникавшие причины и стимулы для переселения в 19181921 гг. требовали определения позиции государства. Сложившееся положение свидетельствовало о наличии «переселенческого тупика», означавшего, с одной стороны, возникновение в различных районах Европейской России потоков переселенцев, а с другой - отсутствие возможности где-либо их устроить [Вощинин 1921: 139]. В условиях НЭПа увеличивавшееся стихийное переселение заставило государство пойти на уступки, открыв плановое переселение.

\section{КОЛОНИЗАЦИЯ И ПЕРЕСЕЛЕНИЕ В УСЛОВИЯХ НЭПА}

Согласно современным представлениям, разработка концепций и идей, охватывающих различные стороны общественной жизни, была характерной чертой НЭПа. В попытке 
учесть довоенный опыт проявилась черта, свойственная НЭПу в целом, вбиравшему «в себя прежде всего отечественные традиции и хозяйственный опыт; воплощение на деле какоголибо иного варианта было просто немыслимо» [Соколов 2001: 10].

Справедливость такой оценки подтверждает концепция колонизации и переселения. Не вдаваясь в подробное изложение этой большой и сложной темы, отметим тесную связь концепции с реформированием переселения (задачей, поставленной в 1910-е годы), с обсуждением перспектив аграрной реформы летом и осенью 1917 г., с достижением «планомерной колонизации» в советские годы, означавшей разработку новой системы государственных мероприятий по организации переселения и культурно-экономическому оживлению окраин. При этом возможности планомерной колонизации в СССР ряд современников оценивал «как беспредельные и чрезвычайно заманчивые» [Вощинин 1919: $10-11]$.

При определении роли переселения в условиях НЭПа учитывался курс на создание благоприятных условий для проявления личной инициативы крестьянства, провозглашенный государством [Ямзин, Вощинин 1926: 80-81]. Предполагалось, что одной из форм такой инициативы станет индивидуальное переселение крестьян.

На первый взгляд, такая оценка роли переселения кажется преувеличенной. Правда, уже в начале 1920-х годов в открытой печати новая модель общественного развития была признана бесперспективной (Бруцкус и др.). Но в конкретных условиях первой половины 1920-х годов позиция ученых по вопросам переселения и колонизации отражала влияние реального положения крестьянства - результаты земельных преобразований, аграрное перенаселение, усиливавшуюся дифференциацию крестьянства, сокращение по сравнению с довоенным временем масштабов отхода на заработки, растущую безработицу в городах, политику правительства в отношении сельского хозяйства и др. У части сельских жителей сохранились довоенные представления о переселении как способе решения насущных вопросов и т.д. Необходимость переселения и колонизации обосновывалась задачами подъема экономики страны - не только сельского хозяйства, но и промышленности, транспорта, увеличения экспорта продукции из районов, богатых различными природными ресурсами.

С учетом названных факторов прогнозировалось обострение переселенческого вопроса в ближайшие годы. Поэтому уже в начале 1920-х годов был поставлен вопрос о согласовании общегосударственных интересов с интересами и стремлением переселенцев, предлагалось разработать меры, позволявшие выйти из отмеченного выше «переселенческого тупика» [Вощинин 1921: 139].

Прежде всего необходимым считалось объявить свободными передвижения, направленные на увеличение производительности труда и земли. Право государства в ограничении свободы передвижений состояло в открытии тех или иных участков для освоения. Мера содействия переселенцам должна была соответствовать степени заинтересованности государства в тех или иных перемещениях. На всей территории Российской Федерации переселенческое дело должно быть организовано на единообразных началах с обеспечением преимущественно общегосударственных интересов. Национальное обособление конкретной территории не могло служить препятствием для свободного 
передвижения переселенцев. Правила о переселении предлагалось распространить в виде популярных изданий. До определения народнохозяйственной целесообразности всякого рода передвижки населения должны были быть объявлены делом индивидуального риска каждого, т.е. без какого-либо участия правительства. На переселенческое дело должны быть ассигнованы достаточные средства, но не меньше, чем в довоенной России (в 1914 г. такие ассигнования составили 30229324 руб., т.е. 18,16\% бюджета Министерства земледелия России) [Вощинин 1921: 140-142].

События в 1920-е годы отразили противоречивое, а в конечном счете негативное отношение государства к переселению и колонизации. Но в первой половине 1920-х годов были приняты меры, определившие научно-организационные и практические предпосылки для разработки колонизационно-переселенческой тематики ${ }^{6}$.

В сложных условиях конца 1910-х годов Наркомат земледелия РСФСР (далее НКЗ РСФСР) организовал две экспедиции по изучению перспектив колонизации Севера Европейской России, объединивших ведущих ученых страны.

В 1922 г. был открыт Государственный научно-исследовательский колонизационный институт (Госколонит). Сходный по названию с институтами в Брюсселе, Лондоне, Риме, Гамбурге и Киле, Госколонит рассматривал колонизационную проблему как плановую сеть мероприятий и комплекс процессов, конечная цель которых состояла в гармоничном развитии производительных сил всей страны, его хозяйственнополитических центров и «сырьевых баз» «сквозь призму органической связи природы и местного населения» [Ямзин 1924: 30]. В институте был создан колонизационнопереселенческий сектор, исследования которого охватывали широкий круг вопросов внутренней и внешней миграции, особенности колонизации разных территорий в России и в зарубежных странах и др.

В составе землеустроительного факультета Московского межевого института началась подготовка специалистов в области колонизации и переселения на базе следующих учебных курсов: общего учения о колонизации и переселении, экономической географии колонизационных процессов, экономики и техники колонизации, иностранной колонизации и др. Теория и практика переселения и колонизации в качестве предмета преподавания в высшей школе были обобщены в учебном пособии [Ямзин, Вощинин 1926].

Кафедру переселения и колонизации на географическом факультете Ленинградского государственного университета возглавил В.П. Вощинин. В 1925 г. на факультете была создана колонизационная секция Географо-экономического института, в рамках которой разрабатывалась концепция комплексной науки - колонизациеведения [Мебус, Вощинин 1926: 10].

В 1926 г. В.П. Вощинин выдвинул идею о колонизационной географии как специальной отрасли общего учения о колонизации [Вощинин 1928: 88-89].

\footnotetext{
${ }^{6}$ В практическом плане - опыт колонизации Мурманской железной дороги. Но эта тема выходит за рамки данной работы.
} 
Вместе с тем разработка вопросов колонизации и переселения включала большие риски. Одним из инструментов национальной политики советского государства на протяжении 1920-х годов, как мы покажем дальше, была острая критика переселенческой политики дореволюционной России и колониальной политики в капиталистических странах. Поэтому стремление вложить новое содержание в «негативный» термин «колонизация» противоречило официальной доктрине. Допускавшееся в начале 1920-х годов сосуществование различных концепций и идей было недолговременным. Изначально оно предполагало победу марксисткой идеологии. В 1927 г. на I Всероссийском совещании работников переселенческого дела термины «колонизация» и «колонизатор» были признаны равнозначными бранному выражению [Платунов 1976: 96].

Учитывая большой опыт довоенной России, СССР и современной России в освоении природных ресурсов различных районов, концепцию колонизации и переселения вряд ли можно отнести к числу неактуальных и непрозорливых. Но ее постановка, также как и содержание, противоречили задачам, которые решались в конце 1920-х годов.

И все же в 1920-е годы вырос интерес к переселенческому делу как комплексу законодательных и организационных мер. Помимо объективных причин, связанных с положением крестьянства, о чем шла речь выше, он был вызван либерализацией законодательства в области внутренней и внешней миграции населения, ставшей необходимым условием НЭПа.

В 1922 г. всем гражданам РСФСР было предоставлено право «беспрепятственного передвижения по всей территории республики в пределах ее федеральных границ до пограничных пунктов» [СУ РСФСР 1922а]. В 1922 г. были смягчены правила выезда за границу граждан РСФСР и иностранцев [СУ РСФСР 1922b]. К 1922 г. был образован СССР. В 1924 г. в СССР было установлено единое союзное гражданство [СУ СССР 1924].

Рассматривая переселение в первой половине 1920-х годов, нельзя не обратить внимание на Конституцию СССР (1924 г.), которая закладывала основы движения населения и рабочей силы на территории СССР. Так, в число предметов ведения верховных органов власти СССР, наряду с общим планом народного хозяйства, единым государственным бюджетом, единой денежной системой и т.д., было включено общесоюзное законодательство о межреспубликанских переселениях и установление переселенческого фонда [Основной Закон... 1940: 42]. Следовательно, межреспубликанские переселения были признаны важным общесоюзным явлением. Но поскольку земля объявлялась объектом государственной собственности, собственности именно республиканской, а не общесоюзной, самый порядок осуществления права на землю и пределы его, зависевшие от свободного запаса земли, предоставлялись законодательству союзной республики, с учетом которого должна была строиться союзная переселенческая политика.

Одновременно в 1921-1924 гг. на совещаниях и съездах, посвященных земельным отношениям, обсуждаются вопросы переселения. Значительное число постановлений, циркуляров, приказов и инструкций по этой проблеме издается НКЗ РСФСР. 
На Всероссийском земельном съезде (декабрь 1921 г.) переселение было признано одной из мер аграрной и социально-экономической политики государства и принято решение о начале подготовки переселенческого фонда в Сибири [Резолюции... 1921: 66].

Определяющую роль сыграл Земельный Кодекс РСФСР, который включил специальный раздел, посвященный переселению (ст. 18, 21, 222, 223 - 226) [СУ РСФСР 1922c]. Переселение и ходачество были объявлены делом свободным и добровольным. Переселение в пределах РСФСР передавалось в ведение НКЗ РСФСР, на который возлагались руководство и контроль по переселенческому делу.

В то же время Земельный Кодекс разделил переселенцев на две категории - плановых и неплановых. Переселение, проводившееся в рамках плана и в установленном порядке, поощрялось с помощью полного или частичного освобождения от исполнения общегосударственных и местных повинностей, а также различных льгот, которые устанавливали соответствующие декреты (законы). Следовательно, государство в первую очередь поддерживало плановых переселенцев. Порядок получения льгот неплановыми переселенцами, изложенный в Примечании к ст. 225 Земельного Кодекса, предусматривал предварительное получение этой группой разрешения местных переселенческих органов на водворение на землях переселенческого фонда или их доприселение к земельным обществам. В то же время неплановые переселенцы в последнюю очередь обеспечивались землей, они не пользовались льготным проездом по железной дороге и др. Правда, в ряде районов, в том числе в Сибири, законодательство применялось в «мягкой форме»: переселенческие организации, как мы покажем ниже, прилагали немало усилий для обустройства самостоятельных переселенцев.

В целом Земельный Кодекс РСФСР признал переселение и установил его принципы - добровольность, свободу, государственную помощь переселенцам. В то же время свобода переселения регламентировалась планами государства. Колонизационная тематика осталась за рамками Земельного Кодекса.

C учетом контрколонизационных и деколонизационных явлений отдельные положения Земельного Кодекса были приспособлены к особым условиям автономных республик и автономных областей РСФСР.

Как видим, в приведенных выше и последующих решениях необходимость переселенческой политики не ставилась под сомнение. Но ее реализация откладывалась в силу ряда условий.

В числе таких условий назывался недостаток финансовых средств, а также необходимость учета интересов местного населения в районах вселения. В 1924 г. совещание губернских земельных управлений поставило задачи постепенного вовлечения в хозяйственный оборот недостаточно обжитых районов, преимущественного переселения из местностей, где аграрное перенаселение было особенно острым, и т.д. В то же время НКЗ РСФСР официально отказался от идеи широкой «выселенческой политики» «с целью массовой переброски избыточного населения малоземельных районов на окраины» в силу ограниченного запаса свободных земель. В итоге колонизационно-переселенческие мероприятия планировались только в двух районах - Поволжье и на Севере Европейской 
России. При этом преимущественным правом на переселение пользовались колхозы и товарищества [К совещанию... 1924: 29-30].

Однако нараставшее давление крестьян на местные советские и земельные органы потребовало пересмотра политики государства.

В 1923 г. ряд губернских земельных управлений обратился к НКЗ РСФСР с требованием разрешить переселение крестьян в многоземельные районы. Брянское губземуправление мотивировало такое требование недостатком земли и ее плохим качеством. Число заявок на переселение, поступивших в НКЗ РСФСР за 1923-1924 гг., составило 30170 семей (154483 человек). Фактическое число желающих переселиться было в несколько раз больше. Витебский губисполком определил число возможных переселенцев в размере 50 тыс. хозяйств (около 300 тыс. человек), Смоленский - 34788 хозяйств (около 300 тыс. человек) [Большаков 1924: 198-199].

На II Всероссийском совещании земельных работников (1924 г.) была поставлена задача поощрения планового переселения. Но из-за «крайней стесненности средств», выделявшихся государством, предлагалось переселять только крестьян, имеющих достаточные средства для устройства в местах вселения. При этом условием переселения должно было стать землеустройство местного населения [Извлечение... 1927: 28].

Постановлением III съезда Советов Союза ССР крестьянам малоземельных районов разрешалось переселяться на свободные земли. Съезд поставил задачи ускорить подготовку этих земель, увеличить финансирование переселения из государственного бюджета [Третий съезд... 1925: 26].

Вместе с тем параллельно с названными выше решениями издавались приказы, инструкции, циркуляры НКЗ РСФСР. В них требовалось «не допускать», «изжить» и даже «запретить» самовольное переселение.

Весной 1924 г. усилилось движение переселенцев по железным дорогам на свободные государственные земли в Самарскую, Саратовскую, Донецкую и КубаноЧерноморскую области. Причиной движения была «неустроенность и упадок крестьянского хозяйства». НКЗ РСФСР снял с себя всякие обязательства по отношению к переселенцам - получение земли, оказание другой помощи [СУ РСФСР 1924а].

В 1925 г. НКЗ РСФСР категорически настаивает на принятии мер против самовольного переселения. Это означало прекращение выдачи земельными органами, РИКами и сельсоветами разрешений на переселение ходокам и «самовольцам», направлявшимся в Уральскую область, на Северный Кавказ, в Крымскую АССР [Переселенческое дело 1927: 137].

Приведенные выше и другие решения 1921-1924 гг. отразили возросшую роль переселенческого аппарата, мировоззрение которого сформировалось в условиях военного коммунизма. М.А. Большаков, в рассматриваемое время начальник Управления переселением НКЗ РСФСР, пишет в 1927 г. о неясности термина «переселение», «отсутствии авторитетного его толкования», задач этого процесса и статей о переселении в Земельном Кодексе РСФСР (1922 г.), имея, по-видимому, в виду руководящие кадры 
республики [Переселенческое дело 1927: 3]. Такое признание - свидетельство недооценки опыта довоенной России и литературы по вопросам переселения и колонизации, опубликованной к этому времени в Советской России.

В целом в 1921-1924 гг. идея проведения переселенческой политики находит поддержку различных институтов государственной власти, прежде всего съездов и совещаний по земельному вопросу. Но такая поддержка носила вынужденный характер и отражала давление на местные органы власти потенциальных переселенцев, усиливавшегося самостоятельного движения крестьян. На проведении переселенческой политики настаивали ученые. Сдержанно-негативную позицию государства поддерживало руководство ряда многоземельных районов. При этом собственные средства на переселение основной части крестьян в советское время уменьшились по сравнению с довоенным временем из-за упадка крестьянского хозяйства в годы войны и революций, а также национализации земли (в предвоенные годы денежные средства переселенцев формировались, в том числе, и за счет продажи земли в местах выхода).

В итоге в 1921-1924 гг. не были определены цели и задачи переселения и переселенческой политики. В то же время начала широко пропагандироваться идея переселения колхозов, товариществ, кооперативов и т.д. В итоге принятые в области переселения решения носили паллиативный характер, свидетельствовавший о недооценке переселения, узких рамках намеченных колонизационно-переселенческих мероприятий.

\section{ПЕРЕСЕЛЕНИЕ И НАЦИОНАЛЬНАЯ ПОЛИТИКА}

Из изложенного выше видно, что кардинальное национально-территориальное переустройство РСФСР, образование СССР (1922 г.), Конституция СССР (1924 г.) оказали большое влияние на переселенческую политику. Позиция работников НКЗ РСФСР по этому вопросу учитывала новые общественно-политические реалии. «Какие бы лозунги не провозглашала советская власть в своей национальной политике, но расценивать ее будут не по этим лозунгам, а по ее практической политике, и с этой стороны те или иные приемы нашей колонизационной работы на окраинах будут наглядным предметным уроком для народов Востока» [Большаков 1923: 483].

Сложность вопросов переселения и колонизации требовала учета многих других факторов. Выше отмечалась исчерпанность легких земель и необходимость перехода к заселению трудноосваиваемых земель. В районах бывшего заселения, прежде всего в Сибири, как мы уже упоминали, необходимо было наделить землей большое число «неприписанных» переселенцев. Землеустройство в Киргизии проводилось в условиях перехода кочевого населения на оседлый образ жизни, размежевания территории между республиками, их внутреннего районирования и т.д. На ситуацию в районах бывшего заселения влияли чрезвычайные обстоятельства - гражданская война в Сибири, восстания в Семиреченской области в 1916 г., жестоко подавленные, засуха и неурожаи в 1917 г., затруднения в снабжении хлебом Туркестана в 1917 г., джут (массовый падеж скота от бескормицы) в Киргизской АССР в 1921-1922 гг. и др. [Среднеазиатский экономический... 1922: 40]. 
Положение переселенцев находилось под воздействием политики коренизации кадров и перевода документации на национальный язык. В начале 1920-х годов началась реэмиграция в Киргизскую Республику. Возвратившиеся реэмигранты освобождались от уплаты единого сельскохозяйственного налога в течение 5 лет со времени водворения на территорию республики [СУ РСФСР 1926].

Обстановку в районах заселения характеризуют также значительные масштабы передвижения населения. Так, в составе сельского населения Казахской АССР перепись 1926 г. зафиксировала существенную величину когорт мигрантов последних лет вселения 7 . Правда, перепись не позволяет определить их характер - внутриреспубликанский или межреспубликанский (таблица 1).

Таблица 1. Распределение основных народностей Казахской АССР в сельских местностях по продолжительности проживания по переписи 1926 г., тыс. человек

\begin{tabular}{|c|c|c|c|c|c|c|c|c|c|}
\hline & \multirow[t]{3}{*}{ Всего } & \multirow{3}{*}{$\begin{array}{c}\text { В том } \\
\text { числе } \\
\text { местные } \\
\text { уроженцы }\end{array}$} & \multicolumn{7}{|c|}{ Неместные уроженцы } \\
\hline & & & \multirow[t]{2}{*}{ всего } & \multicolumn{6}{|c|}{$\begin{array}{c}\text { постоянно проживающие, по продолжительности } \\
\text { проживания и времени вселения }\end{array}$} \\
\hline & & & & $\begin{array}{c}\text { до } 2-\mathrm{x} \\
\text { лет, } \\
1924- \\
1926 \text { гг. }\end{array}$ & $\begin{array}{c}\text { 3-5 лет, } \\
1921- \\
1923 \text { гг. }\end{array}$ & $\begin{array}{c}\text { 6-9 лет, } \\
1917- \\
1920 \text { гг. }\end{array}$ & $\begin{array}{c}10-12 \\
\text { лет, } \\
1914- \\
1916 \text { гг. }\end{array}$ & $\begin{array}{c}\text { 13-19 } \\
\text { лет, } \\
1907- \\
1913 \text { гг. }\end{array}$ & $\begin{array}{c}\text { свыше } \\
20 \text { лет, } \\
\text { до } 1906 \\
\text { г. }\end{array}$ \\
\hline Казахи & 3635,8 & 3110,0 & 514,8 & 56,9 & 91,5 & 59,5 & 36,6 & 44,1 & 128,8 \\
\hline Русские & 996,2 & 641,6 & 346,0 & 60,5 & 73,8 & 43,3 & 18,7 & 57,3 & 55,8 \\
\hline Украинцы & 828,2 & 407,8 & 412,6 & 42,5 & 49,4 & 30,8 & 40,6 & 167,7 & 65,1 \\
\hline
\end{tabular}

Примечание: Без временно проживающих и неустановленных неместных уроженцев.

Источник: [Всесоюзная перепись...1930с: 50-52].

Как видим, в 1926 г. удельный вес местных уроженцев в составе казахов $(84,4 \%)$, русских $(64,9 \%)$ и украинцев $(49,2 \%)$ заметно различался, хотя среди русских и украинцев он был сравнительно высоким. В структуре русских примечательна большая величина двух последних когорт - вселившихся в 1924-1926 гг. (6,1\% общей численности населения и 17,5\% неместных уроженцев) и в 1921-1923 гг. (соответственно 7,4 и 11,5\%). Несмотря на доминирование когорты 1907-1913 гг. вселения (167,7 тыс. человек), в составе украинцев также заметна роль переселенцев последних лет. В целом переселение казахов, русских и украинцев в первой половине 1920-х годов оказывало влияние не только на формирование населения, но и на земельные отношения в Казахской АССР.

Нельзя не отметить, что в официальных документах 1920-х годов национальный вопрос упрощенно объяснялся негативными последствиями довоенной переселенческой политики в Степном крае и Туркестане, задача которой состояла в том, чтобы «насадить в этих районах побольше кулацких элементов из русских крестьян и казаков» [Десятый съезд... 1962: 606]. Идеология земельной реформы на окраинах СССР означала ликвидацию «старых захватов, произведенных в прошлом русскими кулаками и царскими чиновниками

${ }^{7}$ ВЦИК и СНК РСФСР 26.08.1920. приняли декрет об образовании Киргизской ССР в составе РСФСР. В апреле 1925 г. Казахстан стал называться Казахской АССР. В 1936 г. Казахская АССР была преобразована в Казахскую ССР [Даньшин, Лобанов 2008: 426]. 
- колонизаторами, культивировавшими на окраинах национальный гнет» [Трайнин 1923: 28].

В силу сложного решения земельного вопроса, сохранявшегося на протяжении 1920х годов, было запрещено переселение в ряд районов.

Переселение в Киргизскую АССР извне было запрещено впредь до окончания землеустройства кочевого и полукочевого населения [О запрещении... 1925: 4, 5, 7]. Одновременно переселение внутри республики «по почину самого населения» также запрещалось. Неземлеустроенные «внешние переселенцы» были разделены на две группы - «закономерно пользующихся землей» и «пользующихся землей незакономерно». Первая группа - «закономерно пользующиеся землей», включила всех переселившихся в республику до 19 февраля 1918 г. (т.е. времени издания Закона о социалистическом землеустройстве) и с 19 февраля 1918 г. до 31 августа 1922 г. (времени введения Закона о трудовом землепользовании). Все неземлеустроенные переселенцы, вселившиеся до 19 февраля 1918 г., обустраивались на землях, которыми они фактически пользовались. Вторая группа также устраивалась на землях фактического пользования, законно ей предоставленных по трудовой норме земельного наделения оседло-земледельческих районов. В сложном положении оказались переселенцы, не вошедшие в названные две группы и прибывшие в республику самовольно в различное время. Часть из них подлежала выдворению «на место своего прежнего землепользования», другая могла пользоваться землей на платной основе. Губземуправления должны были представить в Киргизский народный комиссариат земледелия (КНКЗ) сведения о переселенцах-самовольцах, подлежащих выдворению.

Кроме того, местные земельные органы не должны были также допускать переселенцев в КАССР из-за ее пределов - в случае «проникновения» такие переселенцы, в первую очередь самовольно переселившиеся внутри КАССР, подлежали немедленному принудительному выдворению в места своего прежнего жительства.

Но уже в середине 1920-х годов стали очевидными негативные последствия земельной реформы. Ее основы получили на местах «различное толкование...Получился перегиб в пользу национального уклона - против пришельцев. Привилегия одной стороны породила игнорирование интересов другой. История повторилась». Особая Комиссия ВЦИК СССР по землеустройству в южных губерниях Казахстана и Киргизии признала «самым больным вопросом» земельной реформы необходимость устройства европейского населения, выселенного в 1921-1922 гг. из своих селений, а также крестьян, самовольно переселившихся в Казахстан и Киргизию после 1916 и 1918 г. Был поставлен вопрос о ходатайстве перед ВЦИК и СНК СССР об оказании помощи разорившимся к этому времени переселенцам, «учитывая их неосведомленность и запутанность земельно-национальных отношений». Речь шла о помощи 20 тыс. хозяйств, или о 100 тыс. человек [Серов 1926: 4344].

Сказанное выше объясняет обратное движение части переселенцев из Азиатской в Европейскую часть СССР, но величину такого движения определить трудно. 
Одним из последствий земельных преобразований, тесно связанных с национальной политикой, стало ограничение переселенческого фонда в Казахстане, Киргизии, Туркмении. Более того, сохранявшаяся на этих территориях межнациональная напряженность стала одной из причин острой критики переселенческой политики в конце 1920-х годов. В конечном счете последствия земельных преобразований в 1920-е годы оказали длительное влияние на миграционные связи между республиками СССР, характер которых изменился под влиянием чрезвычайных обстоятельств в годы Великой Отечественной войны.

\section{ОТКРЫТИЕ ПЛАНОВОГО ПЕРЕСЕЛЕНИЯ}

Переломным моментом в переселении в 1920-е годы современники считали 17 октября 1924 г. - дату принятия постановления Совета Труда и Обороны (далее СТО) «О ближайших задачах колонизации и переселения». В этом документе задача колонизации определяется как вовлечение в хозяйственный оборот необжитых земель с целью увеличения сельскохозяйственной и промышленной продукции путем рационального как с точки зрения общегосударственных, так и местных интересов расселения и эксплуатации естественных богатств колонизуемых районов. Основой колонизационно-переселенческих мероприятий должен был стать общесоюзный план, устанавливавшийся Центральным колонизационным комитетом (Цеколком) при ЦИК $\mathrm{CCCP}^{8}$.

Строгая очередность мероприятий, обозначенная в постановлении, предусматривала: а) землеустройство туземного, кочевого и оседлого населения; б) землеустройство пришлого населения, захватившего и заселившего земли в колонизуемых районах; в) заселение остающихся свободных земель путем переселения. Предпочтение при выборе колонизуемых районов отдавалось тем из них, где в кратчайший срок и с наименьшими затратами государственных средств можно было произвести работы, необходимые для переселения и получения продукции, предназначавшейся для внутреннего потребления и экспорта. В постановлении СТО намечалась реализация широкой программы мер в области колонизации и переселения, согласование колонизационно-переселенческих мероприятий с планами государственных и концессионных предприятий, строительством путей сообщения, реальными возможностями размещения переселенцев, их прочное хозяйственное устройство и своевременная подготовка фонда для заселения. Планы колонизации охватывали не только сельское хозяйство, но и промышленность [Переселенческое дело 1927: 18-19].

Постановление СТО открыло путь для формирования законодательной базы. Характерно, что декрет «О переселенческих товариществах» [СУ РСФСР 1924b] был принят до открытия планового переселения. В нем говорится о преимуществах переселенческих товариществ для хозяйственного устройства переселенцев и «наиболее полного использования самодеятельности переселенцев». Однако членами

\footnotetext{
${ }^{8}$ В 1925 г. Цеколком был преобразован во Всесоюзный переселенческий комитет при ЦИК СССР. 
переселенческого товарищества на этом этапе не могли стать лица, лишенные по Конституции РСФСР права выборов в советы (решение, впоследствии отмененное).

Следующий декрет расширил права НКЗ РСФСР, который мог собственными распоряжениями объявлять ходачество и переселение в районы, закрытые для переселения с помощью приселения к старожилам, устройства переселенцев на землях свободного государственного фонда. Переселенцам и ходокам разрешалось пользоваться действующими льготными переселенческими тарифами [СУ РСФСР 1925а].

После 11-летнего перерыва, вызванного войнами, революциями и политикой военного коммунизма, в РСФСР в 1924-1925 гг. было открыто плановое переселение [СУ РСФСР 1925b]. Планом на 1924-1925 гг. предусматривалось переселение до 50 тыс. человек в Поволжье, до 50 тыс. - в Сибирь, до 30 тыс. - в Дальневосточную область. Как видим, масштабы планового переселения были скромными и, следовательно, речь не шла об удовлетворении потребности населения в переселении.

В 1925 г. вышло также постановление ЦИК и СНК СССР [C3 СССР 1925а], по которому бывшие помещики и их семьи были лишены права на землепользование и проживание в хозяйствах, принадлежавших им до издания декрета «О земле» 26 октября 1917 г. и находившихся полностью или частично в их фактическом пользовании. Выселяемые в соответствии с законом лица наделись землей в пределах трудовой нормы из колонизационно-переселенческого фонда тех губерний, в которых эти лица не имели земельной собственности.

В 1925 г. ориентировочный план переселения был повышен до 145 тыс. человек. География районов заселения включила губернии и уезды (округа) Поволжья, Северного Кавказа, Уральской области, Сибири и Дальнего Востока [СУ РСФСР 1925с].

В соответствии с Конституцией СССР (1924 г.) был организован Всесоюзный переселенческий комитет при ЦИК СССР (далее - ВПК) [C3 СССР 1925b]. На ВПК возлагалось общее руководство переселенческой политикой в стране, согласование и объединение переселенческих мероприятий союзных республик, составление общесоюзного плана на основе согласованных с ВПК перспективных и годовых планов союзных республик, наблюдение за выполнением плана и т.д. В состав ВПК вошли представители всех союзных республик и ряда общесоюзных органов, включая ЦСУ СССР.

В то же время негативные последствия позднего открытия переселения не остались не замеченными: к середине 1920-х годов хозяйственная система страны прошла определенный этап организационного и восстановительного строительства. «Переселенческое же дело, появившееся со значительным опозданием, да к тому же стихийно, ... должно было все эти годы пробивать себе дорогу не в нормальной обстановке, чтобы кое-как закрепиться» [Попов 1929: 16-17].

Одновременно, как показывают циркуляры НКЗ РСФСР, открытие планового переселения означало его абсолютизацию и усиление критики самовольного переселения [Переселенческое дело 1927: 137, 129, 130-132, 138]. 
Один из циркуляров НКЗ РСФСР (1925 г.) запрещал самовольное переселение. Ссылаясь на опыт 40 тыс. переселенцев, прибывших в Сибирский край и ликвидировавших хозяйство на родине, НКЗ РСФСР предупреждал, что переселенцы могут остаться без земли, стать батраками, и рекомендовал ориентироваться на плановое переселение. Одновременно местным органам категорически запрещалось выдавать документы, разрешавшие крестьянам переселение, приискание земли и т.д.

В другом циркуляре (1925 г.) НКЗ РСФСР рекомендует губземуправлениям собирать сведения о переселении «с максимальной осторожностью», не давать населению «какихлибо обещаний о переселении» и не порождать у населения «напрасных надежд и бесцельных ликвидаций имущества и хозяйства на родине» [Переселенческое дело 1927].

В ответ на поступавшие от краевых, областных и губернских земельных управлений запросы НКЗ РСФСР (1926 г.) разъясняет невозможность достаточно широкого переселения. Местным органам не рекомендуется «поощрять стремление крестьянства к переселению», которое должно быть только плановым. Поэтому «поездки ходоков в Москву для личных ходатайств о переселении вызовут только излишнюю трату времени и денег...От таких напрасных поездок надо население всемерно удерживать» [Переселенческое дело 1927].

В 1926 г. НКЗ РСФСР снова ставит вопрос о принятии энергичных мер по «недопущению самовольного переселения» [Переселенческое дело 1927].

Современники откровенно признали плановое переселение в Сибирь и на Дальний Восток вынужденной мерой, принятой под сильнейшим давлением крестьянства перенаселенных районов [Рубинский 1927: 61; Движение в Сибкрай... 1928: 109].

В сложившихся условиях плановое переселение не предполагало значительных масштабов. В то же время из-за потребности сельского населения в миграции (концепция, разрабатывавшаяся в середине 1920-х годов для борьбы с растущим малоземельем) необходимо было увеличить масштабы отхода на заработки и переселение. Не вдаваясь в детали расчетов, отметим, что в четырех районах Европейской части РСФСР (ЦентральноПромышленном, Центрально-Земледельческом, Северо-Западном и Западном) потребность крестьян во внеземледельческих заработках была определена в размере около 8 млн человек (в 1906-1910 гг. масштабы отхода составляли около 6 млн человек), в переселении - около 300 тыс. человек ежегодно [Турчанинов 1926: 332-376].

Существенный разрыв между потребностью в переселении и масштабами планового переселения показывают губернские земельные органы (таблицы 2 и 3).

Причины хронического разрыва между заявками региональных земельных органов на переселение и возможностью их удовлетворения нашли отражение в популярной литературе ${ }^{9}$.

9 В ответ на вопрос, почему советская власть «не удовлетворяет “тягу к переселению”» всех желающих переселиться, следовало объяснение: «Для этого у советской власти не хватает ни средств, ни подготовленной 
Таблица 2. Заявки мест на переселение на 1926 г., душевых долей

\begin{tabular}{|c|c|c|c|c|c|c|}
\hline & Всего & $\begin{array}{c}\text { Северный } \\
\text { Кавказ } \\
\end{array}$ & Поволжье & $\begin{array}{c}\text { Уральская } \\
\text { область }\end{array}$ & Сибирь & $\begin{array}{c}\text { Дальний } \\
\text { Восток }\end{array}$ \\
\hline Воронежская & 11000 & 2500 & - & 2500 & 3000 & 3000 \\
\hline Курская & 20000 & 4000 & 2000 & - & 8000 & 6000 \\
\hline Орловская & 32000 & 10000 & 1000 & - & 15000 & 5000 \\
\hline Тамбовская & 20000 & - & 3500 & 13000 & 13000 & 3500 \\
\hline Тульская & 14000 & - & 1000 & 1000 & 9000 & 3000 \\
\hline Пензенская & 30000 & - & 5000 & - & 17500 & 7500 \\
\hline Брянская & 20000 & 7000 & 5800 & 2200 & 4200 & 800 \\
\hline Гомельская & 20000 & 5000 & 4000 & 2000 & 7000 & 2000 \\
\hline Рязанская & 12000 & 1000 & - & 1000 & 7000 & 3000 \\
\hline Нижегородская & 12000 & - & 5000 & - & 6000 & 1000 \\
\hline Смоленская & 10000 & - & - & - & 7000 & 3000 \\
\hline Псковская & 18000 & - & - & - & 14000 & 4000 \\
\hline Саратовская & 35000 & - & 35000 & - & - & - \\
\hline $\begin{array}{l}\text { Чувашская } \\
\text { республика }\end{array}$ & 25000 & - & 10000 & 5000 & - & \\
\hline $\begin{array}{l}\text { Белорусская } \\
\text { ССР }\end{array}$ & 77600 & 5000 & - & 5000 & 60000 & 7600 \\
\hline Украинская ССР & 60000 & 20000 & 7000 & 3000 & 15000 & 15000 \\
\hline Всего & 416600 & 54500 & 79300 & 16700 & 190700 & 64400 \\
\hline Всего, \% & 100 & 13 & 19 & 4 & 46 & 15 \\
\hline
\end{tabular}

Источник: [Циркуляр НКЗ... 1927: 133].

Таблица 3. Разверстка отдела колонизации и переселения НКЗ РСФСР душевых долей

\begin{tabular}{|c|c|c|c|c|c|c|}
\hline & Всего & $\begin{array}{c}\text { Северный } \\
\text { Кавказ }\end{array}$ & Поволжье & $\begin{array}{c}\text { Уральская } \\
\text { область }\end{array}$ & Сибирь & $\begin{array}{c}\text { Дальний } \\
\text { Восток }\end{array}$ \\
\hline Воронежская & 2000 & - & 1000 & 500 & 500 & - \\
\hline Курская & 10000 & - & 2000 & - & 6000 & 2000 \\
\hline Орловская & 10000 & - & 1000 & 500 & 6000 & 2500 \\
\hline Тамбовская & 11000 & - & 2000 & 1000 & 6000 & 2000 \\
\hline Тульская & 4500 & - & 1000 & 1000 & 1000 & 1500 \\
\hline Пензенская & 12000 & - & 4000 & 2000 & 3000 & 2000 \\
\hline Брянская & 13000 & - & 6000 & 2000 & 3000 & 2000 \\
\hline Гомельская & 12000 & - & 3000 & - & 5000 & 4000 \\
\hline Рязанская & 3000 & - & - & & 2000 & 1000 \\
\hline Нижегородская & 3500 & - & 2000 & - & 500 & 1000 \\
\hline Смоленская & 2000 & - & - & - & 1000 & 1000 \\
\hline Псковская & 2000 & - & - & - & 1000 & 1000 \\
\hline Саратовская & 15000 & - & 15000 & - & - & - \\
\hline $\begin{array}{l}\text { Чувашская } \\
\text { республика }\end{array}$ & 4000 & - & 3000 & - & 1000 & - \\
\hline Белорусская ССР & 15000 & - & - & - & 9000 & 6000 \\
\hline Украинская ССР & 40000 & - & 20000 & 10000 & 5000 & 5000 \\
\hline Всего & 159000 & - & 60000 & 17000 & 50000 & 32000 \\
\hline Всего, \% & 100 & - & 38 & 11 & 31 & 20 \\
\hline
\end{tabular}

Источник: [Циркуляр НКЗ... 1927: 133].

для занятия переселенцами земли» [Баров 1928: 26]. В 1929 г. возможности государства в переселении из малоземельных районов оценивались в размере 200 тыс. человек в год [Баров 1929: 24]. 
Остановимся на документах, составивших нормативную основу переселенческого дела.

Отдел колонизации и переселения управления землеустройства, мелиорации и госземимуществ НКЗ РСФСР был тем органом, в ведении которого находились, за некоторым исключением, все стадии колонизации и переселения.

Опубликованные НКЗ РСФСР «Правила по колонизации и переселению» (1925 г.) включили тринадцать разделов. Районы заселения должны были подбираться по возможности аналогичными природно-климатическим условиям района выхода переселенцев. Так называемая разверстка переселенческих контингентов между областями, губерниями и республиками должна была учитывать спрос населения на переселение. Необходимым условием подбора переселенцев в местах выхода в первые годы была проверка их материального обеспечения. Она определялась как сумма средств, необходимых для подготовки переселенческого участка, приобретения инвентаря, возведения жилых и хозяйственных построек, оплаты переезда по льготному тарифу и т.д.

К переселению в Сибирь и на Дальний Восток допускались хозяйства, имевшие не менее 2,5 работников и материальное обеспечение в деньгах, инвентаре и постройках не меньше 800 руб. для Сибири, 900 руб. для Дальневосточного края. В случае коллективного переселения такая обеспеченность снижалась до 200 руб. Необходимая сумма материальной обеспеченности снижалась, если число членов в рабочем возрасте в семье превышало число неработающих [Переселенческое дело 1927: 142-143].

На основании соответствующих документов люди получали переселенческое удостоверение и свидетельство на проезд семьи и провоз багажа и инвентаря по льготным тарифам.

Переселенцы в Сибирь и на Дальний Восток освобождались от уплаты единого сельскохозяйственного налога на срок от 3 до 5 лет в зависимости от трудности освоения участка. Отсрочка от призыва на военную службу предоставлялась на срок до 3 лет. Бесплатным был отпуск строевого леса.

В последующие годы льготы изменились. В 1927 г. были увеличены ссуды переселенцам, водворявшимся на фондах союзного значения [Известия ЦИК 1928а]. Эти ссуды были предназначены на хозяйственное обустройство (возведение построек, приобретение скота, инвентаря, семян и т.д.), на обустройство территории, выдавались как кооперированным организациям переселенцев, так и отдельным хозяйствам. Средний размер ссуды на крестьянское хозяйство определялся в размере 300-600 руб. (в зависимости от района), ссудный процент - 3,5\%, срок погашения ссуды достигал 10 лет (на Дальнем Востоке - до 17 лет). Но и такой размер ссуд считался недостаточными для эффективного развития хозяйства переселенцев.

В 1928 г. были расширены льготы по переселению красным партизанам и красногвардейцам, а также детям убитых красных партизан и красногвардейцев. Эти категории переселенцев получали земли в районах, открытых для переселения, в первую 
очередь. Им полагались также повышенные размеры ссуд на обзаведение домашнего хозяйства и др. [Известия ЦИК 1928b].

В 1928 г. были уставлены более благоприятные условия для переселения коллективных хозяйств. [Известия ЦИК 1928с].

Как видим, открытие планового переселения явилось важным событием. Но его масштабы были незначительными. Переселенческая политика, опиравшаяся на плановое переселение и его коллективные формы, означала недооценку самостоятельного переселения, занимавшего важное место в миграционных планах крестьянства ряда районов Европейской части СССР. Сложившийся «дуализм» в переселении имел существенные последствия. Фактически самостоятельное переселение стало вызовом плановому. В конце 1920-х годов оно стало рассматриваться как свидетельство «кризиса» переселения.

\section{ПЕРЕСЕЛЕНЧЕСКАЯ СТАТИСТИКА}

Опыт дореволюционной России показал большую роль различных источников данных для анализа переселения. С начала 1880-х годов эволюция источников состояла, с одной стороны, в улучшении переселенческой статистики, с другой - в проведении обследований потенциальных и реальных переселенцев в местах выхода и вселения, выполнявшихся Переселенческим управлением и, главным образом, земскими статистиками. Нельзя не отметить регулярную публикацию данных статистики Переселенческим управлением.

С открытием планового переселения в РСФСР в 1924-1925 гг. началась регистрация прямого и обратного движения переселенцев и ходоков. По «Положению об органах Наркомзема РСФСР, ведающих делом передвижения переселенцев» (август 1926 г.), руководство и наблюдение за правильностью ведения статистического учета и регистрации ходаческого и переселенческого движения и своевременной разработкой материала возлагались на заведующих передвижением переселенцев на переселенческих пунктах. Такие пункты были расположены в крупных узловых и пересадочных станциях Челябинске, Свердловске, Сызрани и Иркутске [Переселенческое дело 1927: 83-84].

Регистрация переселенцев включала широкий круг вопросов: 1) состав переселяющейся семьи по полу, возрасту, грамотности и национальности главы семьи с учетом членов семьи, оставшихся дома, переселяющихся в данный момент и переселившихся раньше; 2) место выхода; 3) место вселения; 4) документ, по которому переселяются; 5) на какую землю переселяются (по приемному договору, зачисленную на переселенческом участке и т.д.); 6) основные занятия; 7) размер земельного обеспечения на месте выхода; 8) форма землепользования; 10) способы ликвидации землепользования, 11) причина переселения. Особые программы регистрации были разработаны для ходоков и обратных переселенцев. Кроме этого, как мы отмечали выше, переселению предшествовало обследование экономического положения переселяющихся семей и кооперативных объединений в местах выхода. 
Одновременно с переселенческой статистикой была введен учет регистрации переселенцами земельного участка и водворения их на этом участке. Это означало подведение итогов следующего этапа переселения - водворения.

Как видим, переселенческая статистика в 1920-е годы позволяла проанализировать важнейшие параметры переселения - его масштабы, направления, состав переселенцев, прямое и обратное движение и т.д. Правда, постановка отдельных вопросов априори предполагала неполные и даже недостоверные ответы. В 1925 - 1926 гг. на вопрос о размере выручки, полученной от ликвидации переселенческого хозяйства, было собрано только $25 \%$ ответов. Но и они вызывали сомнение - у переселенца не было особого желания указывать переселенческой организации, на помощь которой он рассчитывал, имевшиеся у него денежные средства [Красильников 1928: 107]. Однако вскоре выявились принципиальные недостатки организации регистрации переселенцев. Они проявились в существенных расхождениях сведений НКЗ союзных республик и данных регистрации на перевалочных пунктах. Считалось, что регистрация охватит плановых и самовольных переселенцев. Так, в 1924-1925 гг. общее число переселенцев составило 102 тыс. Из них было зарегистрировано 47 тыс. (46\%). В 1926-1927 гг. эти показатели составили соответственно 160 и 104 тыс. (65\%). Причиной расхождений стала неполная регистрация самовольных переселенцев, которые «по понятным причинам» избегали регистрации на переселенческих пунктах.

О сложившемся положении пишет М.Н. Красильников, который, судя по публикациям во второй половине 1920-х годов, принимал участие в организации переселенческой статистики. «Двигаясь большими массами, самовольные переселенцы обременяют переселенческие органы на местах прихода своими претензиями на право получения земельных участков, создают всякого рода путаницу, загружают пункты разгрузки и в результате срывают переселенческий план данного года». Помимо неприязненного отношения к самостоятельным переселенцам, неполная их регистрация объяснялась способом их перемещения - в общих пассажирских вагонах, а не в специальных вагонах для переселенцев [Красильников 1929: 91].

В итоге переселенческая статистика неполно учитывала масштабы и состав переселения. В рамках господствующей идеологии акцент в сборе и обработке данных был сделан на плановых переселенцах, в конце 1920-х годов - на их классовом составе. В то же время движение самовольных переселенцев явно недооценивалось. Нетрудно предположить незаинтересованность НКЗ РСФСР и других государственных организаций в получении достоверных сведений о масштабах и структуре самовольных переселенцев, отношение к которым определялось догмой о преимуществах планового переселения, т.е. переселения колхозов, а не единоличного крестьянского хозяйства. Отметим, что дореволюционная переселенческая статистика охватывала различные категории переселенцев, включая самовольных, при этом много внимания уделяла разработке данных именно об этой категории.

Нельзя не обратить внимание на заметно упавший интерес к обследованию переселенческих хозяйств. В то же время региональные переселенческие организации столкнулись с нехваткой сведений об экономике переселенческого хозяйства. По- 
видимому, первые обследования таких хозяйств были проведены переселенческим отделом Сибирского края. Они охватили неприписное население, не имевшее земли, а также переселенцев-самовольцев, выделенных в особую социальную категорию [Юрцовский 1928: 64-68; Движение в Сибкрай... 1928: 109-126].

В целом переселенческая статистика после 1924-1925 гг., хотя и дает известное представление о переселении, находилась в стадии становления. Некоторые исходные данные, например, о масштабах переселения, противоречивы. Поэтому опубликованные данные требуют известной осторожности при использовании. Кроме того, в силу различной методологии учета, трудно сравнить характеристики переселенцев в 1920-е годы с довоенными.

\section{ДИНАМИКА И СТРУКТУРА ПЕРЕСЕЛЕНИЯ}

Первые результаты анализа переселенческой статистики показали сходные черты переселения во второй половине 1920-х годов и в довоенное время. Этот вывод основывался на данных о составе переселенцев, общих районах выхода, значительном удельном весе самовольцев и др.

Как и в довоенное время, переселение в 1920-е годы было возможно только при ассигновании государством значительных средств (таблица 4).

Таблица 4. Динамика ассигнований на переселения в СССР, тыс. руб.

\begin{tabular}{|c|c|c|}
\hline Год & Всего ассигновано & В том числе ссуды переселенцам \\
\hline 1913 & 27284,3 & 10200,0 \\
\hline $1922-1923$. & 50,9 & 6,9 \\
\hline $1923-1924$ & 498,4 & 373,5 \\
\hline $1924-1925$ & 1562,8 & 1036,0 \\
\hline $1925-1926$ & 6189,0 & 3490,0 \\
\hline $1926-1927$ & 22610,7 & 9933,2 \\
\hline $1927-1928$ & 26356,7 & 7772,0 \\
\hline
\end{tabular}

Источник: [Великевич 1928a: 66].

Данные таблицы 4 показывают существенный рост ассигнований на переселение. Примечательными стали 1927-1928 гг., когда ассигнования формально достигли уровня 1913 г. ${ }^{10}$ Но в силу роста цен на рабочую силу, машины и материалы переселенческие мероприятия в СССР уступали довоенным [Великевич 1928а: 66].

Динамика расходов на ссуды переселенцам имела особое значение в силу их бедности, особенно, начиная с весны 1927 г., когда были отменены ограничения на переселение бедных и средних групп переселенцев. Как видно из таблицы 4, реализация этой меры потребовала более чем двухкратного увеличения расходов по этой статье в 19261927 гг. В 1913 г. удельный вес расходов на ссуды переселенцев составил 37,4\%. В советские годы этот показатель устойчиво снижался - с 66,3\% в 1924-1925 гг., 56,8 \% в 1925-

${ }^{10}$ В 1913 г. число переселившихся за Урал (ходоков и переселенцев) составило 308 тыс., обратных (семейных) было 23 тыс. или 11\% [Кауфман 1915b: 2-3]. 
1926 гг., 43,9\% в 1926-1927 гг. до 29,5\% в 1927-1928 гг. Такая тенденция объясняется ростом других статей, прежде всего на подготовку «трудных» земель для заселения.

Возраставшие ассигнования государства определили рост масштабов переселения (таблица 5).

Таблица 5. Динамика числа переселенцев в 1924-1930 гг.

\begin{tabular}{c|c}
\cline { 2 - 3 } Год & Число переселенцев, чел. \\
\hline $1924-1925$ & 103871 \\
$1925-1926$ & 108587 \\
$1926-1927$ & 142771 \\
$1927-1928$ & 173773 \\
$1928-1929$ & 320987 \\
Октябрь 1929 - сентябрь 1930 & 121555 \\
\end{tabular}

В целом масштабы переселения во второй половине 1920-х годов соответствовали показателям переселенческого движения в 1895-1905 гг., т.е. до его подъема в 1906 г. Увеличение масштабов переселения в 1928-1929 гг. объясняется включением межрайонных переселенцев в состав переселенцев РСФСР. В 1928-1929 гг. число переселенцев, по сравнению с предыдущим годом, выросло незначительно - в РСФСР почти на 10 тыс., в УССР - на 13 тыс., в БССР - почти на 8 тыс. Интенсивность переселения сельских жителей в 1928-1929 гг. на 10 тыс. человек из БССР составила 144, УССР - 28 человек, РСФСР - 22 человека [Красильников 1930: 85].

По другим данным, в течение 1924/25-1930 гг. только в Сибири было зарегистрировано около 910 тыс. переселенцев: в 1924-1925 гг. - 100212 человек, в 19251926 гг. - 100411 человек, в 1926-1927 гг. - 80000 человек, в 1927-1928 гг. - 247190 человек, в 1928-1929 гг. - 260448 человек, с октября 1929 г. по сентябрь 1930 г. - 121555 человек [Платунов 1976: 82]. Как видим, динамика переселения в Сибирь, основанная, повидимому, на более полном учете всех групп переселенцев, в чем были заинтересованы местные переселенческие органы, позволяет сделать более определенный вывод о возраставших масштабах переселения в этот район. Правда, в данном случае, возможно, были учтены переселенцы в пределах Сибири в связи с ее деколонизацией, о чем шла речь выше.

Следуя методологии анализа состава переселенцев, выработанной в довоенных исследованиях, рассмотрим прежде всего величину земельного надела, считавшуюся ключевым показателем положения переселенческого хозяйства в местах выхода (таблица 6). Но поскольку термин «земельный надел» в переселенческой статистике не был точно обозначен, трудно сравнивать величину земельного надела не только с довоенным показателем, но и с данными текущей земельной статистики 1920-х годов, быстрое развитие которой определялось переходом к единому сельскохозяйственному налогу.

Известно, что последствия земельных преобразований в РСФСР (СССР) оказались дискуссионными. Очевидно, что в составе переселенцев в 1920-е годы, по сравнению с довоенным временем, снизилась доля безземельных. Вместе с тем преобладающей группой по-прежнему были малоземельные крестьяне. Их удельный вес (с наделом до 1 га) вместе 
с безземельными достиг 86,1\%. В Центрально-Черноземных областях доля этой группы составила 89,2\%, среди выходцев из Украины - 78,6\%, из Белоруссии - 87,3\%.

Таблица 6. Распределение переселенцев по размеру земельного надела в месте выхода в 1925 и 1926 г.

\begin{tabular}{|c|c|c|c|c|c|c|c|c|c|c|}
\hline & \multirow{2}{*}{\multicolumn{2}{|c|}{ Всего }} & \multicolumn{8}{|c|}{ В том числе } \\
\hline & & & \multicolumn{2}{|c|}{$\begin{array}{c}\text { Центрально- } \\
\text { Черноземные } \\
\text { области }\end{array}$} & \multicolumn{2}{|c|}{$\begin{array}{c}\text { Средневолжские } \\
\text { области }\end{array}$} & \multicolumn{2}{|c|}{ Украина } & \multicolumn{2}{|c|}{ Белоруссия } \\
\hline & $\begin{array}{l}\text { абс. } \\
\text { вел. }\end{array}$ & $\begin{array}{l}\text { в \% к } \\
\text { итогу }\end{array}$ & $\begin{array}{l}\text { абс. } \\
\text { вел. }\end{array}$ & $\begin{array}{l}\text { в \% к } \\
\text { итогу }\end{array}$ & $\begin{array}{l}\text { абс. } \\
\text { вел. }\end{array}$ & $\begin{array}{l}\text { в \% к } \\
\text { итогу }\end{array}$ & $\begin{array}{l}\text { абс. } \\
\text { вел. }\end{array}$ & $\begin{array}{l}\text { в \% к } \\
\text { итогу }\end{array}$ & $\begin{array}{l}\text { абс. } \\
\text { вел. }\end{array}$ & $\begin{array}{l}\text { в \% к } \\
\text { итогу }\end{array}$ \\
\hline Безземельные & 3306 & 10,3 & 421 & 5,0 & 449 & 6,5 & 686 & 14,9 & 727 & 16,2 \\
\hline \multicolumn{11}{|c|}{ С наделом на душу: } \\
\hline до 0,54 га & 12651 & 39,3 & 3109 & 37,1 & 3399 & 49,9 & 1610 & 35,1 & 1792 & 40,2 \\
\hline от 0,55 до 1,09 га & $\lfloor 1752$ & 36,5 & 3978 & 47,5 & 2383 & 35,1 & 1312 & 28,6 & 1384 & 30,9 \\
\hline от 1,1 до 1,64 га & 2367 & 7,4 & 606 & 7,2 & 361 & 5,3 & 350 & 7,7 & 349 & 7,9 \\
\hline от 1,65 до 2,18 га & 676 & 2,1 & 88 & 1,1 & 68 & 1,0 & 164 & 3,6 & 104 & 2,3 \\
\hline свыше 2,19 га & 641 & 2,0 & 56 & 0,7 & 76 & 1,2 & 134 & 2,9 & 58 & 1,3 \\
\hline неизвестно & 786 & 2,4 & 120 & 1,4 & 68 & 1,0 & 335 & 7,2 & 54 & 1,2 \\
\hline
\end{tabular}

Малоземелье основной части переселенцев объясняет причину их переселения. Согласно ориентировочным расчетам потребность в переселении крестьянской семьи наступала при обеспеченности ее землей в размере 0,65 десятин на едока [Турчанинов 1926: $373]$.

С отменой ограничений на переселение малоимущих слоев после 1926 г. число малоземельных крестьян увеличилось. Последствия таких изменений нетрудно предугадать. Они означали необходимость возрастающей помощи государства, медленный подъем, потребительский характер и низкую товарность переселенческого хозяйства в районах вселения, что не могло не оказывать сдерживающего влияния на развитие районов заселения.

Как и в довоенное время, в переселении 1920-х годов участвовали преимущественно большие семьи, средняя величина которых в 1925-1928 гг. колебалась в интервале 5,7-5,9 человек. Относительно стабильным был удельный вес семей из 4-5 и 6-7 человек, доля которых в 1928 г. составляла 64,5\%. Важной демографической характеристикой переселенческой семьи оставалась высокая доля лиц в рабочем возрасте. В 1928 г. 48\% мужчин и $51 \%$ женщин среди переселенцев были в рабочем возрасте, что соответствовало условиям переселения. Удельный вес грамотных, хотя и повышался, но оставался низким, особенно женщин. В 1928 г. грамотными среди переселенцев было 39\% мужчин и 8\% женщин [Красильников 1930: 87-88].

Районы выхода переселенцев не отличались существенно от довоенных. Эту особенность наглядно подтверждают заявки на переселение (в то время как фактическое переселение корректировалось влиянием неурожая и другими факторами). В 1924 г. доля Центрально-Черноземного района в общем числе заявок составила $30 \%$, Западного (вместе с Белоруссией) - 22\%, Центрально-Промышленного района - 16\%, Средневолжского - $13 \%$, Северо-Восточного - 2\%, Северо-Западного - 4\%, Украинской ССР - 6\% и др. [Ямзин 1927: 57]. 
Структура районов вселения отразила изменившуюся в 1920-е годы географию переселенческих потоков (таблица 7).

Таблица 7. Районы вселения переселенцев, \%

\begin{tabular}{l|c|c|c|r|r}
\hline & $1924-$ & $1925-$ & $1926-$ & $1927-$ & $1928-$ \\
& 1925 гг. & 1926 гг. & 1927 гг. & 1928 гг. & 1929 гг. \\
\hline Сибирский край & 63,6 & 55,2 & 35,8 & 44,9 & 62,9 \\
Дальневосточный край & 4,9 & 10,3 & 28,4 & 29,3 & 11,8 \\
Казакская АССР и Киргизская АССР & 21,8 & 7,9 & 6,7 & 4,6 & 7,2 \\
Уральская область & 4,5 & 5,1 & 14,0 & 9,9 & 10,6 \\
Северный Кавказ & - & 10,7 & 3,3 & 1,3 & 0,5 \\
Поволжье & 2,3 & 7,9 & 11,1 & 9,3 & 3,9 \\
Другие районы & 2,9 & 2,9 & 0,7 & 0,7 & 3,1 \\
\hline \multicolumn{1}{c}{ Источник: [Красильников 1930: 87]. }
\end{tabular}

Большинство переселенцев (около 85\%) направлялось в Сибирский край, на Дальний Восток и Уральскую область, что соответствовало задачам переселения, сформулированным в официальных документах. При этом доля Дальневосточного края и Уральской области увеличивалась, в то время как значение Северного Кавказа, Поволжья, Казахской АССР и Киргизской АССР сокращалась.

Переселение в 1920-е годы оставалось движением единоличных крестьянских хозяйств, доля которых в 1925 г. составляла 92,6\%, в то время как удельный вес коллективных переселенцев был 0,2\%, неизвестных - 7,0\% [Красильников 1930: 88].

В 1928-1929 гг. обратное движение составило 19\% к прямому движению за этот год. История переселенческого движения в России показывает, что процесс перемещения неизменно сопровождался обратным движением, хотя его масштабы и структура существенно различались по периодам, в разной степени вовлекая переселенцев разных лет. Поэтому для объяснения причин обратного движения необходим тщательный анализ исходных данных за ряд лет. В данном случае привлекает внимание не только негативная оценка обратничества (рассматриваемого как следствие «стихии единоличных хозяйств»), но и его перспективы (обратное движение должно было сойти на нет» при переселении целыми колхозами) [Красильников 1930: 90].

Одной из важнейших характеристик переселения в 1920-е годы была доля самовольных переселенцев. В 1925-1928 гг. их удельный вес в общем числе переселенцев оценивался в размере около 1/3 [Красильников 1930: 87]. Однако с учетом состояния переселенческой статистики этот показатель в ряде районов был более высоким (таблица $8)$.

В 1928 г. большие масштабы движения самовольных переселенцев и ходоков были отмечены в Сибири и в Крыму, что объясняется, по-видимому, привлекательностью этих районов, традициями переселения и большой ролью родственных связей. Ниже мы специально остановимся на обследовании самовольцев в Сибирском крае. Их значительное число подтверждает большой интерес крестьян к перемещению в условиях неопределенных перспектив планового переселения. В конце 1920-х годов самовольное движение стало бегством от надвигавшихся потрясений общественной жизни, связанных с коллективизацией. 
Таблица 8. Движение переселенцев и ходоков в 1928 г.

\begin{tabular}{|c|c|c|c|c|c|c|c|}
\hline & \multicolumn{3}{|c|}{ Переселенцы } & \multicolumn{3}{|c|}{ Ходоки } & \multirow[t]{2}{*}{ Всего } \\
\hline & плановые & неплановые & всего & плановые & неплановые & всего & \\
\hline Дальний Восток & 39020 & 11654 & 50674 & 5406 & 2156 & 7562 & 58236 \\
\hline Сибирь & 46766 & 31222 & 77988 & 6503 & 2173 & 8676 & 86664 \\
\hline Урал & 14122 & 3265 & 17387 & 1721 & 536 & 2257 & 19644 \\
\hline Поволжье & 13215 & 3068 & 16283 & 992 & 571 & 1563 & 17846 \\
\hline Северный Кавказ & 2053 & 374 & 2427 & 341 & 1069 & 1410 & 3837 \\
\hline Крым & 834 & 8180 & 9014 & 53 & 398 & 451 & 9465 \\
\hline Итого & 116010 & 57763 & 173773 & 15016 & 6903 & 21919 & 195692 \\
\hline $\begin{array}{l}\text { Удельный вес } \\
\text { плановых } \\
\text { переселенцев }\end{array}$ & 67 & 33 & 100 & 67 & 33 & 100 & \\
\hline
\end{tabular}

Примечание: Без прочих.

Источник: [Лясковский 1929: 109].

В целом, несмотря на непродолжительный период наблюдения и недостатки переселенческой статистики, характеристики переселения в 1920-е годы были сходными с довоенными. Основной его чертой в 1920-е годы стало увеличение масштабов, связанное с ростом государственных ассигнований. Переселение довоенное и 1920-х годов объединяет преобладание малообеспеченных слоев крестьян, их значительный демографический потенциал, общие районы выхода, низкий уровень образования, а также высокая доля самостоятельных переселенцев.

\section{САМОВОЛЬНЫЕ ПЕРЕСЕЛЕНЦЫ}

Во второй половине 1920-х годов самовольное движение, заставившее государство открыть плановое переселение, рассматривалось как временное и чуждое новой общественной системе явление. Поэтому предполагалось, что масштабы самовольного движения сократятся под влиянием увеличения планового переселения. Такая точка зрения, главным образом работников НКЗ РСФСР и ВПК СССР на страницах журнала «Вестник землеустройства и переселения», отразила идеологическую предвзятость, непонимание объективного характера самовольного движения, недооценку довоенного опыта, убежденность в эффективности действующих мер.

В то же время в конце 1920-х годов еще высказывалась идея предоставления земли пионерам-засельщикам (самовольцам), переселявшимся «за свой риск и страх» [Ямзин 1928: 84]. Обоснованность такой точки зрения подтвердило обследование самовольцев, проведенное Сибирским переселенческим отделом зимой 1927 г.

В соответствии с принятой идеологией Сибирский переселенческий отдел считал самовольные передвижения «угрозой планомерности земельного устройства сибирского населения на новых началах» [Движение в Сибкрай... 1928: 109]. Но реальное положение показывало не только устойчивость, но и положительные функции этого движения. Значительная доля самовольцев в Сибири была признана характерной чертой движения населения из Европейской России за Урал на протяжении многих десятилетий. 
Обследование обратило внимание на особые характеристики самовольцев. В их числе была названа чуткая реакция на отношение государства к переселению, на политикоэкономические события, происходившие в стране.

По неполным данным железнодорожной статистики и сибирских земельных органов, в 1914-1921 гг. в Сибирь прибыло 33082 плановых переселенцев, 276590 «самовольцев», 170481 беженцев войны и 259320 беженцев от голода - всего 739473 человека. С октября 1925 г. по октябрь 1926 г. в Сибири было зарегистрировано 100411 переселенцев, в том числе 26741 плановых и 73670 (73,4\%) самовольцев. Удельный вес самовольцев приблизился к величине, зафиксированной в России в 1880-е годы. При этом большая часть самовольцев в середине 1920-х годов «исчезла из поля наблюдения переселенческой организации» [Движение в Сибкрай 1928: 110-111].

По сравнению с плановыми переселенцами самовольцев отличала высокая приспособляемость к местным условиям: они активнее закреплялись в старожильческих обществах и на легкоосваиваемых землях. Самовольцы чаще оседали в западных районах Сибири и меньше передвигались на Дальний Восток. Характерно, что более 50\% самовольцев стремились устроиться самостоятельно, без содействия переселенческой организации [Движение в Сибкрай... 1928: 112-113]. Места их выхода были названы «устойчивыми гнездами» - общими для довоенного времени и для второй половины 1920х годов. В число «гнезд» были включены Самарская, Пермская, Саратовская, Ульяновская, Уфимская губернии. В сознании населения этих губерний, как утверждают авторы обследования, прочно укоренилось представление о предпочтительном самовольном переселении. Такое поведение переехавших определило расхождения между данными отдела переселения НКЗ РСФСР и фактическим переселением, имевшим с момента зарождения «признаки стихийного движения» [Движение в Сибкрай... 1928: 114].

Причины переселения, названные самовольцами, были сформулированы следующим образом: «не мог ждать очереди» $(30,4 \%)$, «не подбиралась партия» $(0,8 \%)$, «не знал порядка» $(8,7 \%)$, «как бедняк не получил разрешения» $(16,10 \%)$, «как одинокий» $(0,8 \%)$, «не было разрешения на переселение» $(42,7 \%)$ и др. Как видим, названные причины наглядно отразили противоречие между ограниченными масштабами планового переселения и стремлением крестьян сменить место жительства. Состав семьи «самовольцев» (на 1,3 едока меньший, чем семья планового переселенца) свидетельствовал о реакции на сложные условия переселения. Из-за повышенных рисков группа зажиточного крестьянства среди самовольцев достигла 50\% [Движение в Сибкрай... 1928: 122]. Обследование выявило также важную роль в переселении связей самовольцев с выехавшими ранее.

Как в итоге объяснялось самовольное переселение и что предлагалось предпринять по результатам обследования?

По мнению авторов обследования, основными причинами движения самовольцев были «слабость госаппарата в местах выхода» и, как следствие, отсутствие информации о правилах (порядке) переселения; устойчивая убежденность крестьян в предпочтительном самовольном устройстве в Сибирском крае и др. Трудно не согласиться с мнением о 
необходимости улучшения информированности переселенцев (задачи, не решенной в довоенной России). Но возможности информационного ресурса преувеличены.

В целом самовольное движение было признано не только массовым и устойчивым, но и почти легализованным явлением. В практике работы переселенческого отдела Сибири самовольцы, получая землю, ссуды на домообзаводство и другие льготы, фактически приравнивались к плановым переселенцам. Такой подход отразил не только традиции работы довоенного Переселенческого управления, но и признание этой категории переселенцев «деятельным элементом», от которого можно было «ожидать большого производственно-хозяйственного эффекта для Сибири».

И все же в борьбе с «отрицательными последствиями» самовольного движения предлагалась тщательная проработка планов НКЗ РСФСР по отбору переселенцев; организация широкого информирования переселенцев, их регистрация в едином пункте (в Челябинске) для улучшения учета и последующего распределения по районам Сибири. В то же время предлагалось выделить в Сибири районы для свободного их заселения самовольцами, а также проведение широких обследований плановых и самостоятельных переселенцев [Движение в Сибкрай... 1928: 126].

Следовательно, речь шла о более полном использовании потенциала самовольного движения для социально-экономического развития районов заселения. Но такие выводы и предложения не могли существенно повлиять на переселенческую политику.

\section{НОВЫЕ РЕШЕНИЯ. РАЗРАБОТКА ПЕРСПЕКТИВНОГО ПЛАНА ПЕРЕСЕЛЕНИЯ НА ЗЕМЕЛЬНЫЕ ФОНДЫ ОБЩЕСОЮЗНОГО ЗНАЧЕНИЯ}

Как уже упоминалось, с переходом к НЭПу плановое переселение стало рассматриваться как часть общей задачи по укреплению народного хозяйства и развитию производительных сил страны. В 1926-1928 гг. были приняты шаги, предусматривавшие повышение роли переселения в социально-экономическом развитии. Предлагавшиеся на исходе НЭПа меры отразили, по-видимому, возросшее влияние ВПК при ЦИК СССР, а также трудности снижения городской безработицы, попытку уменьшить негативные последствия аграрного перенаселения, борьбу с самовольным движением, потребности в притоке населения ряда восточных районов.

1926 г. стал первым годом финансирования мероприятий по смете ВПК при ЦИК СССР. Несмотря на рост финансирования (до 21,2 млн руб. в 1926 г. по сравнению с 8 млн руб. в 1925 г.), его величина отставала от потребностей из-за перехода на трудноосваиваемые земли [Сахаров 1927а: 137-138]. При этом в конце 1920-х годов число желающих переселиться превышало в 10 раз возможности государства [Лацис 1928: 9-10].

Принятые в 1926-1928 гг. постановления предусматривали повышение роли переселения в социально-экономическом развитии страны. Так, постановлением Президиума ЦИК СССР от 30.07.1926 «О задачах переселения и порядке финансирования переселенческих мероприятий» предусматривалось улучшение финансирования переселения и его масштабов в ближайшие 10 лет до 5 млн человек [Лацис 1927: 9-10]. 
В связи с этим выросло внимание к вопросам эффективности переселения. Первые публикации по этой теме обнадеживали. Но для дальнейших исследований необходимы были не только соответствующая информация и дискуссия, но и подведение итогов переселенческой политики в довоенное время ${ }^{11}$.

Помимо улучшения финансирования, повышение роли переселения означало новый подход к формированию переселенческих фондов: в ряде губерний Европейской России, в Сибири и большинстве автономных республик, местные органы которых отрицали наличие свободной земли до окончания землеустройства «своего населения». Особое внимание привлекали автономные республики (Казахстан, Башкирия, Бурят-Монголия и др.), где, как считалось, имелись избыточные земли, хотя республики своевременно не представили планы, показывавшие наличие и использование таких земель [Лацис 1927: 9, 12].

С общегосударственной точки зрения, позиция руководства многоземельных районов, отрицавшая необходимость переселения, оценивалась, исходя из недоиспользования земельного фонда этих районов. Одновременно ряд районов Европейской части, в их числе и Украина, лишились возможности переселить избыточное население. Важным было и то, что заселение степей Казахстана стоило примерно на 40\% меньше, чем освоение лесных пространств. По расчетам ВПК СССР, закрытие Казахстана для союзного переселения требовало дополнительных затрат для подготовки и заселения лесных фондов около 1 млд руб., а недоиспользование легких избыточных земель могло замедлить экономический рост Казахстана [Лацис 1927: 11-12].

Перед союзными и автономными республиками была поставлена задача разработать план переселенческих мероприятий. Попытки республик «наглухо закрыть свои границы от вторжения неплановых переселенцев» не были поддержаны ВПК СССР. Недопустимой была признана практика земельных органов, увеличивавших земельные нормы для местного населения и оставлявших резервные земли в расчете на естественный прирост населения [Большаков 1926: 6, 8-9].

На 3-ем совещании наркомов земледелия (ноябрь 1926 г.) было найдено компромиссное решение - к 1927 г. предстояло завершить разработку перспективных планов переселения всех союзных и автономных республик в качестве условия подготовки сводного плана ВПК СССР [Смирнов 1926: 3].

Постановление «О задачах переселения, его организации, основах составления планов переселения и о порядке финансирования переселенческих мероприятий» от 18.01.1928 [СУ СССР... 1928] также предусматривало увеличение роли переселения. Но постановление 1928 г. стало, по-видимому, последним, в котором были обозначены позитивные планы государства в этой области.

Задачи переселения в этом постановлении были сформулированы традиционно освоение необжитых и малообжитых территорий, разгрузка перенаселенных районов и регулирование самовольного движения. Региональные задачи переселенческой политики состояли в заселении Дальневосточного края (с Сахалином и Камчаткой), Сибирского края

${ }^{11}$ См. [Жданов 1929: 30-45; Говберг 1929: 22-38] и др. 
с примыкающими к нему частями Уральской области и Карело-Мурманского края. Общесоюзный переселенческий план предусматривал также заселение свободных земель в ряде районов Северо-Кавказского края, северной части Крымской АССР, Поволжья и южных частей Уральской области. Одновременно предстояло выявить переселенческие фонды в Казахской, Башкирской, Бурято-Монгольской и других автономных республиках. Однако здесь приоритетным оставалось местное расселение, а после него - переселение из других республик. Кроме того, для переселения планировалось использование богарных и орошаемых земель в районах строившейся Туркестано-Сибирской железной дороги и др. Планы переселения предстояло согласовать с планами развития промышленности и организации промыслов, строительством железных дорог общегосударственного значения.

Переселенческие фонды, создававшиеся в Дальневосточном, Сибирском краях, на севере Крымской АССР и в ряде других районов, были признаны общесоюзными, т.е. открытыми для переселения из РСФСР и других союзных республик.

Постановление 1928 г. утвердило также новый порядок финансирования, разделив переселение на общесоюзное и республиканское. К общесоюзному бюджету относились расходы, связанные с заселением переселенческих фондов общесоюзного значения. Они включали расходы по обследованию, изучению, выявлению переселенческих фондов, по связанному с ним землеустройству, по разбивке переселенческих фондов, проведению дорог, производству мелиорации, выдаче ссуд переселенцам и т.д. Планы переселения и расселения внутри союзных республик находились в ведении НКЗ соответствующих республик. Расходы по выявлению перенаселенных районов и их разгрузке, организации выхода и информирования переселенцев были отнесены к бюджету союзных республик по месту выхода.

Наконец, постановлением 1928 г. предусматривалась разработка общесоюзного плана переселения на 10-15 лет. Одновременно правительства союзных республик должны были составить перспективные планы внутри- и межреспубликанских переселений [Новицкий 1928: 131].

Тенденция расширения переселенческой политики проявилась в предоставлении Бирско-Биробиджанского района Дальневосточного края для переселения трудящихся евреев [Сахаров 1928c: 96]. Но эта тема выходит за рамки нашего исследования.

Как уже упоминалось, план ВПК СССР на две ближайшие пятилетки предусматривал переселение на союзные земельные фонды около 5 млн человек. В то же время предложения союзных республик по переселению превышали 10 млн человек. При переселении предлагалось сохранить сходство природных условий мест выхода и вселения и сократить самовольное переселение в результате роста планового переселенческого фонда [Лацис 1927: 13]. Пятилетний план на 1928/29-1932/33 гг. включал подготовку земельного фонда на 1,6 млн человек и переселение 1,47 млн человек. В основном это были лесные (80\%), лесостепные (10\%) и степные (10\%) земли. 90\% земель были отнесены к необжитым. Стоимость переселенческих мероприятий оценивалась в 250,7 млн руб. Из этой суммы подготовка земельного фонда требовала 109,2 млн руб. [Сахаров 1927b: 118]. Таким образом, ежегодные ассигнования только на переселение на фонды союзного значения должны были увеличиться до 50 млн руб. в год. 
Преимущественное внимание в перспективных планах уделялось заселению Дальнего Востока. В этом районе планировалось подготовить земельный фонд на 611 тыс. человек и переселить 468 тыс. человек. В Сибирском крае эти показатели должны были составить соответственно 638 и 592 тыс. человек, в Уральской области - 167 и 164 тыс., на Севере Европейской части - 107 и 78 тыс., в Поволжье - 80,0 и 151 тыс. человек и т.д. Северный Казахстан рассматривался как район крупного увеличения зерновой продукции и животноводства для экспорта и внутренних рынков СССР за счет вовлечения в сельскохозяйственный оборот степей севера республики. После землеустройства коренного населения ориентировочная площадь избыточных земель в этой республике оценивалась в 33 млн га, демографическая емкость - свыше 3 млн человек. Последнее означало удвоение населения Северного Казахстана [Сахаров 1928а: 140-146].

Реализация плана переселения означала сдвиг населения в восточные районы, прежде всего в Сибирь и на Дальний Восток. В целом постановления 1926-1928 гг. можно считать успехом работы ВПК при ЦИК СССР и НКЗ РСФСР. Однако вывод о том, что «вопросы переселения в жизни наших окраин заняли одно из выдающихся мест среди прочих народнохозяйственных факторов» [Сахаров 1927b: 119], оказался преждевременным.

Планировавшееся в 1928 г. утверждение пятилетнего план переселения СНК СССР и Президиума ЦИК СССР [Сахаров 1928b: 147], по-видимому, не состоялось. Мы не нашли в открытой печати сведений о решениях по этому вопросу. Более того, в условиях острой общественно-политической ситуации в конце 1920-х годов перспективы реализации планов переселения вызывали острую критику. В итоге лишились будущего не только намеченные планы переселения, но и индивидуальное переселение крестьян, и научное направление, посвященное изучению вопросов переселения и колонизации.

В настоящее время планы переселения представляют теоретический интерес как альтернатива движению населения, реально сложившемуся на рубеже 1920-1930-х годов.

\section{КРИТИКА ПЕРЕСЕЛЕНЧЕСКОГО ДЕЛА. ЗАКРЫТИЕ ПЕРЕСЕЛЕНИЯ}

Как видим, во второй половине 1920-х годов была предпринята попытка расширить рамки переселенческого дела. Его организация на основе перспективных планов требовала существенного увеличения финансирования. Она затрагивала интересы ряда автономных республик. Эти причины вызвали острую критику переселения и переселенческой политики.

Из предыдущего изложения видно, что в 1920-е годы переселение находилось под пристальным вниманием государства, задача которого состояла в снижении напряженности в деревне, сокращении самовольного движения. В то же время разработка перспективных планов переселения поставила ряд вопросов, требовавших новых решений. В числе таких вопросов были масштабы, организация и эффективность переселения.

Положительные итоги переселения в сельской местности Сибири и Дальнего Востока отразила перепись 1926 г. (таблица 10). 


\section{Таблица 10. Население по продолжительности проживания в сельских местностях Сибирского и Дальневосточного краев по переписи 1926 г., тыс. чел.}

\begin{tabular}{|c|c|c|c|c|c|c|c|c|c|}
\hline & \multirow[t]{3}{*}{ Всего } & \multirow{3}{*}{$\begin{array}{c}\text { В том } \\
\text { числе } \\
\text { местные } \\
\text { уроженцы }\end{array}$} & \multicolumn{7}{|c|}{ Неместные уроженцы } \\
\hline & & & \multirow[t]{2}{*}{ всего } & \multicolumn{6}{|c|}{$\begin{array}{c}\text { постоянно проживающие, по продолжительности } \\
\text { проживания и времени вселения }\end{array}$} \\
\hline & & & & $\begin{array}{c}\text { до 2-х } \\
\text { лет, } \\
1924- \\
1926 \\
\text { гг. }\end{array}$ & $\begin{array}{c}3-5 \\
\text { лет, } \\
1921- \\
1923 \\
\text { гг. }\end{array}$ & $\begin{array}{c}6-9 \\
\text { лет, } \\
1917- \\
1920 \\
\text { гг. }\end{array}$ & $\begin{array}{c}10-12 \\
\text { лет, } \\
1914- \\
1916 \\
\text { гг. }\end{array}$ & $\begin{array}{c}13-19 \\
\text { лет, } \\
1907- \\
1913 \\
\text { гг. }\end{array}$ & $\begin{array}{c}\text { свыше } 20 \\
\text { лет, до } \\
1906 \text { г. }\end{array}$ \\
\hline Сибирский край & 7556,0 & 4768,0 & 2729,4 & 460,0 & 386,9 & 323,4 & 129,7 & 693,7 & 607,7 \\
\hline $\begin{array}{l}\text { Дальневосточный } \\
\text { край }\end{array}$ & 1408,9 & 811,2 & 580,6 & 113,0 & 75,0 & 54,4 & 34,6 & 106,7 & 108,1 \\
\hline
\end{tabular}

Примечание: Без временно проживающих и неустановленных неместных уроженщев.

Источник: [Всесоюзная перепись... 1930а: 79; 1930b: 63].

Величина когорт мигрантов 1924-1926 гг. (460,0 тыс.) и 1921-1923 гг. (386,9 тыс.) в сельской местности Сибирского края была значительной, хотя и уступала довоенной численности. Обе когорты составили 31,0\% неместных уроженцев и $11,2 \%$ сельского населения Сибирского края. На Дальнем Востоке эти показатели были выше соответственно 32,3 и $13,3 \%$.

По другим данным, ежегодный прирост населения Сибири за 1925-1928 гг. составил 3,0-3,5\%, Дальнего Востока - 4,6-6,7\%, СССР - 1,6\%, РСФСР - 2,3\% [Лясковский 1929: 114].

Помимо увеличения численности населения, переселение позволяло решить целый ряд других вопросов: планово организовать территорию страны, уменьшить наплыв безработных в города, вовлечь в народнохозяйственный оборот пустующие пространства, увеличить на этих территориях выпуск продукции для внутреннего потребления и экспорта, прочно и быстро заселить ряд пограничных районов [Лацис 1927: 10; Попов 1929: 19]. Правда, расчеты избыточного труда в сельском хозяйстве (Госплан СССР - 7 млн человек, ВПК при ЦИК СССР - 21 млн, НКЗ УССР - 20,9 млн человек и др.) показывали, как и в довоенное время, что роль переселения в уменьшении аграрного перенаселения Европейской России могла быть ограниченной: даже перемещение 5,2 млн человек могло поглотить не более $30 \%$ общей величины избыточного труда в сельском хозяйстве [Ямзин 1927: 51].

Но результаты переселения, так же, как и другие аргументы в пользу переселенческой политики, остались без внимания. В конце 1920-х годов обсуждение вопросов переселения и переселенческой политики было направлено прежде всего на дискредитацию переселения индивидуальных крестьянских хозяйств. Хотя большое значение переселения в экономическом развитии страны не отрицалось, решающим стало отрицание «колонизационных возможностей» мелких крестьянских хозяйств, критика высокой доли самовольцев и соответственно низкой доли коллективных хозяйств различного типа и совхозов в переселенческом движении. Так, признав наличие существенных недочетов (по терминологии НКЗ РСФСР - дефектов) в организации всех стадий переселенческого дела, «главным дефектом» работы переселенческого аппарата в 
местах выхода было названо движение десятков тысяч разрозненных крестьянских хозяйств [Большаков 1928: 5-6].

Учитывая начальный этап заселения, недооценку довоенного опыта, сложности финансирования, нетрудно было определить различного рода «дефекты» в районах вселения. Они состояли в неудовлетворительной подготовке земельного фонда, в обострении отношений переселенцев с местным населением Сибири и Дальнего Востока, у которого изымались излишки земли. В обследованных районах Сибири и Дальнего Востока уровень подготовки земли для переселенцев не превышал 30-40\%, что во многом определяло их неудачи, переход на другие участки и т.д. Агрономическая и ветеринарная помощь среднестатистическому переселенческому хозяйству, планировавшаяся в размере 19 руб. 50 коп. в год, составила фактически 3 руб. 70 коп. Время в пути на Дальний Восток достигало 1-1,5 месяца [Большаков 1928: 17-24]. Неустойчивое состояние экономики переселенческих хозяйств объяснялось также просчетами в организации переселенческого дела. По данным Омской переселенческой партии, в первый год вселения не имели земли $34,25 \%$ хозяйств, во второй - 12,17\%. Без инвентаря было соответственно 34,48 и 35,30\% хозяйств. Вывод о том, что крайняя бедность переселенческих хозяйств в сочетании со слабой подготовкой заселяемых районов к хозяйственному использованию, со слабостью хозяйственного и культурного обслуживания переселенцев, «граничившей с заброшенностью», «не может создать гарантии прочной приживаемости», не был преувеличением. Исходя из этого, экономический эффект переселения, даже при незаметном его влиянии на разрежение аграрного перенаселения в районах выхода, «вызывал большие сомнения» в положительном влиянии на развитие районов водворения.

Последовательная и, по-видимому, спланированная критика состояния переселенческого дела сосредоточилась на главном - несовместимости переселения «с элементами социалистической реконструкции нашего народного хозяйства, с расползанием по новым землям сотен тысяч разрозненных индивидуальных крестьянских хозяйств» (разрядка Великевича И.- В.М.) [Великевич 1928а: 71].

Напомним, что задача увеличения коллективных хозяйств в составе переселенцев была сформулирована на 2-ом совещании земельных работников (1924 г). В последующие годы переселенческая политика отдавала явное предпочтение коллективному переселению, предлагая внеочередное переселение, внеочередную выдачу кредитов, преимущества в прокладывании дорог, строительстве школ, больниц и т.д.

Большим недостатком переселенческого дела было признано сходство переселения в советские годы и в дореволюционное время. В то же время, учитывая непродолжительное время существования переселения в 1920-е годы, трудно согласиться с «расходованием огромнейших средств» на него: их величина была несопоставима, например, с расходами на безработицу в СССР.

Улучшить переселенческое дело предлагалось за счет чистки аппарата и увольнения бывших работников Переселенческого управления, поскольку части из них были «чужды наши задачи и цели» [Великевич 1928а: 83]. 
Новый этап критики переселенческого дела отразил итоги работы Всесоюзного переселенческого совещания при ВПК при ЦИК СССР (1929 г.). Хотя на совещании традиционно отмечалась важная роль переселения в притоке рабочих рук для развития сельского хозяйства и промышленности Дальневосточного и Сибирского краев, новому этапу переселения, как отмечалось, должны были соответствовать четко обозначенные цели: «скорейшее освоение неосвоенных земельных и промышленных богатств указанных выше районов Союза ССР путем увеличения количества населения этих районов и создания на базе социалистического строительства новых сельскохозяйственных и промышленных производственных единиц, реально способствующих росту сельскохозяйственной и промышленной продукции». Решение таких задач не соответствовало, как считалось, возможностям переселения. Поэтому «индивидуальное переселение должно быть в возможно короткий срок заменено широким колхозным строительством». Одновременно был поставлен вопрос о промышленном и промысловом переселении как условия индустриализации страны, которое должно было стать ведущим в реорганизации переселенческих мероприятий [Основные задачи... 1929: 10- 11].

Наркомат Рабоче-крестьянской инспекции СССР пришел к выводу о «зачаточном состоянии», в котором находилось переселение и о переживаемом им кризисе [Попов 1929: 16]. Между тем в 1928-1929 гг. произошло повышение масштабов переселения, сопровождавшееся ростом самовольного движения в Сибирь. Его величина достигла ориентировочно 130-140 тыс. человек [Вестник землеустройства... 1929: 105].

В этих условиях 1928-1929 гг. стали переломными в переселенческом деле. Реализация нового подхода означала, во-первых, соблюдение классового принципа в организации переселения, во-вторых, коллективизацию переселенческого движения, втретьих, отмену ходачества и переход к переселению так называемых рабочих дружин. Предлагалось также отказаться от выполнения переселением функций разгрузки аграрноперенаселенных районов [Шулейкин 1930: 98-99].

Новые задачи переселенческого дела отразили переориентацию народнохозяйственного развития страны на ускоренную индустриализацию. В кратчайшие сроки в районах заселения предлагалось построить переселенческие колхозные хозяйства и «достичь максимальной производительности этих земель на базе машинизированного крупного производства» с тем, чтобы переселенческие колхозы «с первых лет своего существования оказывались в состоянии... сдавать государству максимально-возможное количество зерновой продукции» [Основные задачи... 1929: 11-13].

Со второй половины 1929 г. льготное переселение крестьян-единоличников было отменено. Государство финансировало только колхозное переселение. В 1930 г. в Сибирь прибыл 14421 колхозник-переселенец [Платунов 1976: 94].

Постановление ЦИК и СНК СССР от 2 июля 1930 г. передавало общее руководство общесоюзным переселенческим фондом в ведение Народного комиссариата земледелия СССР. Руководство переселением рабочих для строительства, промышленности и транспорта было поручено Народному комиссариату труда СССР. Одновременно НКЗ СССР должен был уточнить перечень районов, имевших общесоюзное значение, и 
разработать план переселения на ближайшие 3 года [Переселенческое дело на... 1930: 9495].

Таким образом, в конце 1920-х годов индивидуальное переселение крестьян, вынужденно введенное в середине 1920-х годов, было отменено. Главной причиной отмены стало несоответствие его функций новым общественно-политическим задачам. Тем самым остались нереализованными планы переселения многих сотен тысяч крестьян из аграрноперенаселенных районов Европейской России за Урал. По существу, это была первая в советские годы попытка реализовать задачу заселения Сибири и Дальнего Востока. В последующие десятилетия такая задача неоднократно провозглашалась, но осталась нерешенной на протяжении всего XX века.

\section{ЛИКВИДАЦИЯ ИССЛЕДОВАНИЙ ПЕРЕСЕЛЕНИЯ И КОЛОНИЗАЦИИ КАК НАУЧНОГО НАПРАВЛЕНИЯ}

Отрицательная оценка состояния переселенческого дела и ликвидация переселения индивидуальных хозяйств означали острую критику организации и результатов исследований в области переселения и колонизации. Параллельность этих процессов была, по-видимому, очевидна для современников

В 1928 г. небольшая брошюра А.Н. Небольсина [1928] вызвала острую критику за использование теории либерально-народнических (т.е. дореволюционных) ученых при объяснении причин и характера переселения крестьян в Воронежской губернии. Кроме того, в работе отсутствовали указания переселенческим органам в местах выхода по организации переселения как планового мероприятия [Великевич 1928b: 119-121]. Негативная рецензия на брошюру Небольсина означала отрицание малоземелья как причины переселения.

Последующая критика сосредоточилась на публикациях ведущих ученых и организаций. Первым в этом ряду стал в 1929 г. НИИ землеустройства и переселения, организованный, как уже упоминалось, в 1922 г. постановлением СНК РСФСР в Москве как Госколонит в составе Главнауки Наркомпроса РСФСР. В институте работал первый в стране колонизационно-переселенческий сектор ${ }^{12}$. К 1930 г. труды института составили 12 томов. Попытки показать целесообразность сохранения института не дали результата. В 1930 г. институт был передан в ведение НКЗ РСФСР «для более тесных связей с производством», что означало его ликвидацию как самостоятельного учреждения [Рудин 1930: 23-26].

Другое направление критики связано с работами В.П. Вощинина, которые были опубликованы в трех сборниках Географо-экономического института при географическом факультете ЛГУ в 1926-1928 гг. В этих публикациях, как мы показали выше, получили развитие взгляды В.П. Вощинина на процесс колонизации и переселения в России, которые

\footnotetext{
${ }^{12}$ Отчет о работе колонизационного сектора содержит статья К.В. Космачевского [1928: 138-147]. 
были признаны немарксистскими, мальтузианскими, т.е. ненаучными и неграмотными [Чешихин 1930: 76-85; М.Ц. 1930: 139-144].

Сложное положение с землеустройством в ряде районов, в том числе и в Казахстане, стало причиной критики «переселенческих чиновников старого режима» - специалистов НКЗ РСФСР, «снова начинавших поднимать свои колонизаторские головы» (Чепракова, Чиркина, Рудина и др.). Взамен исследования вопросов переселения и колонизации предлагалась новая система планирования миграции, которая должна была быть только плановой. Учитывая важную роль миграции рабочей силы из деревни для реализации пятилетнего плана, плановым органам (Госплану СССР, ВСНХ, НКТ СССР, НКЗ СССР) предлагалось составить особый план передвижения населения. Он, учитывая потребности городской индустрии и заселения, должен был указать «куда и откуда и в каком количестве должна быть переброшена рабочая сила. Это будет своего рода мобилизационный план, наподобие военного мобилизационного плана, рассчитанного во времени и пространстве» [Сластухин 1930: 48].

«Простой арифметический подход» стал основой для вывода об отсутствии аграрного перенаселения в ряде районов Европейской России. Вполне достаточное количество земли у «излишних» рабочих рук в деревне снимало задачу усиления переселения, ставившуюся перед партией [Садвокасов 1928: 62-63].

Как видим, за короткий период 1917-1929 гг. переселение в РСФСР и СССР прошло сложный процесс эволюции от полного отрицания переселения, вынужденного разрешения планового переселения, роста и определенного влияния планового и самостоятельного передвижения до преобразования этого процесса в переселение колхозов и совхозов. В итоге была выдвинута идея полного подчинения переселения задачам государства, поставленная в период военного коммунизма и означавшая окончание процесса переселения и расселения крестьянского хозяйства - одного из длительных и важных по последствиям процессов в истории России. Благоприятные демографические и научноорганизационные предпосылки для заселения ряда районов страны (Сибири, Дальнего Востока), имевшиеся в 1920-е годы, остались нереализованными.

\section{ЛИТЕРАТУРА}

Баров А. (1928). Переселение на новые земли. М.-Л. 2-е изд.

Баров А. (1929). Куда и как переселяться. М.

Белевский А.А. (1904). К переселенческому вопросу // Русское богатство. № 1.

Беркенгейм А.М. (1902). Переселенческое дело в Сибири (По личным наблюдениям и официальным данным). М.

Большаков М. (1923). Задачи и перспективы колонизации // На новых путях. Итоги экономической политики 1921-1922 гг. Вып. V. Ч. 1. Сельское хозяйство. М.

Большаков М. (1924). К плану колонизационно-переселенческих мероприятий на 1923 1924 гг. // Труды Государственного колонизационного научно-исследовательского института. Т.1. М. 
Большаков М. (1926). Положение переселенческого дела в СССР // Сельскохозяйственная жизнь. № 49.

Большаков М. (1928). Дальневосточное и сибирское переселение (По материалам обследования Наркомзема РСФСР) // Вестник землеустройства и переселения. № 4.

Великевич И. (1928а). Переселенческое дело в СССР, его недостатки и основные задачи // Вестник землеустройства и переселения. № 9.

Великевич.И. (1928b). Переселенческое движение крестьян из Воронежской губернии // Вестник землеустройства и переселения. № 10.

Вощинин В.П. (1912). Переселенческий вопрос в Государственной Думе III созыва. Итоги и перспективы. СПб.

Вощинин В.П. (1919). Государственные неотложные задачи колонизации // Очередные вопросы колонизации. Вып. І. Север Европейской России / Под ред. В.П. Вощинина. Петроград.

Вощинин В.П. (1921). Переселение // О земле. Вып. 1. Сборник статей о прошлом и будущем земельно-хозяйственного строительства. М.

Вощинин В.П. (1928). Работы ГЭИИ в области колонизациеведения (По секции прикладной географии) // Сборник географо-исследовательского института за 1927 г / Под ред. Н.И. Кузнецова и С.А. Советова. Л.

Всесоюзная перепись населения 1926 года (1930а). Т. 40. М.

Всесоюзная перепись населения 1926 года (1930b). T.41. М.

Всесоюзная перепись населения 1926 года (1930c). Т. 42. М.

Всесоюзная перепись населения 1926 года (1931). Т. 51. М.

Говберг Г. (1929). Переселение и его влияние на народное хозяйство // Вестник землеустройства и переселения. № 6 .

Даньшин А.И., М.М. Лобанов (2008). Казахстан / Большая Российская энциклопедия. Т. 12. M.

Движение в Сибкрай переселенцев-самовольцев (1928) // Вестник землеустройства и переселения. № 6.

Десятый съезд РКП(б). Март 1921 г. Стенографический отчет (1962). М.

Жданов Б.Н. (1929). К вопросу об эффективности затрат на переселение // Вестник землеустройства и переселения. № 4.

Журнал заседаний Комиссии по вопросам переселения и колонизации. Заседание 7 августа 1917 г. (1917a) // Вопросы колонизации. Период. сборник / Под ред. Г.Ф. Чиркина. № 20. Пг.

Журнал заседаний Комиссии по вопросам переселения и колонизации от 22-го августа и 22-го сентября 1917 года (1917b) // Вопросы колонизации. Период. Сборник. № 20. Пг.

Известия ЦИК (1928а). № 22.

Известия ЦИК (1928b). № 89.

Известия ЦИК (1928c). № 94. 
Извлечение из резолюции 2-го Всероссийского совещания земельных работников. 2-8 марта 1924 года. Переселение (1927) // Переселенческое дело. Сборник декретов и распоряжений по переселению / Под ред. и с предисл. М.А. Большакова.

К совещанию губернских земельных управлений. Тезисы докладов управлений и хозорганов НКЗ (1924). М.

Кауфман А.А. (1915a). Переселения и переселенческий вопрос в России // Энциклопедический словарь Русского Библиографического института. Седьмое издание. Т.31. М.: Гранат.

Кауфман А.А. (1915b). Переселенческая статистика (раздельная пагинация) // Энциклопедический словарь Русского Библиографического института. Седьмое издание. Т.31. М.: Гранат.

Кауфман А.А. (1918). Переселение и его возможная роль в земельной реформе // Отд. отт. статьи из журнала «Сельское хозяйство и лесоводство». Т. 256. Пг.

Кенарский Л. (1924). Колонизация и переселения в Киргизский край (Историческая справка) // Советская Киргизия. № 11-12.

Космачевский К.В. (1928). Пятилетний план деятельности Государственного НИИ землеустройства и переселения // Вестник землеустройства и переселения. № 4.

Красильников М. (1928). Состав переселенцев // Статистическое обозрение. № 12.

Красильников М. (1930). Аграрное переселение в 1928/29 г. // Статистическое обозрение. № 5 .

Красильников М.П. (1929). К постановке переселенческой статистики // Вестник статистики. № 2 .

Лацис М.И. (1927). Текущие вопросы переселенческого дела // Вестник землеустройства и переселения. № 1.

Лацис М.И. (1928). О колхозном и совхозном строительстве в районах заселения // Вестник землеустройства и переселения. № 5.

Ленский Н. (1914). Самовольные переселенцы и переселенческое законодательство // Вопросы колонизации. Период. сб-к / Под ред. Г.Ф. Чиркина и Н.А. Гаврилова. № 14. СПб.

Лясковский Г. (1929). Предварительные итоги переселения за 1928 г. и ориентировочные контрольные цифры на 1929 г. // Вестник землеустройства и переселения. № 1.

М.Ц. [Рецензия] (1930). Учение о колонизации и переселениях // На аграрном фронте. № 2.

Мебус Г.А., В.П. Вощинин (1926). Задачи секции прикладной географии // Сборник географо-экономического института (при географическом факультете ЛГУ) за 1926 г. / Под ред. Н.И. Кузнецова и С.А. Советова. Л.

Небольсин А.Н. (1928). Переселенческое движение крестьян из Воронежской губернии / Под ред. и с предисл. А.Н. Татарчука. Воронеж.

Новицкий И.Б. (1928). Закон и практика землеустройства и переселения (15 января 20февраля 1928 года) // Вестник землеустройства и переселения. № 5.

О запрещении переселения в КССР из-за пределов ее, самовольного переселения внутри ее и о мероприятиях в отношении земельного устройства уже переселившихся (1925). Оренбург. 
Огановский Н.П. (1917). Проблема перераспределения земельного фонда и ее роль в современной аграрной реформе // Основные вопросы аграрной реформы на 2-ом Всероссийском съезде Лиги аграрных реформ. Серия А. № 2. М.

Огановский Н.П. (1921). Народное хозяйство Сибири. Эпизодический курс лекций, прочитанных на кооперативных курсах для слушателей и рабочих кооперативных организаций гор. Омска в феврале-марте 1920-г года. С 12-ю диаграммами и картограммами. Омск.

Огановский. Н.П. (1914). Закономерность аграрной эволюции. Т. III. Обновление земледельческой России и аграрная политика. Вып. I. Население. Переселенческий вопрос. Саратов.

Основной Закон (Конституция) Союза Советских Социалистических республик (Утвержден II Съездом Советов Союза СССР) (1940) // Конституции и конституционные акты Союза СССР (1922-1936). Сборник документов / Под ред. И.П. Трайнина. М.

Основные задачи Всесоюзного переселенческого совещания при Переселенческом комитете ЦИКа Союза ССР (1929) // Вестник землеустройства и переселения. № 9.

Переселенческое дело (1927) // Сборник декретов и распоряжений по переселению / Под ред. и с предисл. М.А. Большакова. М.

Переселенческое дело на новых путях (1930) // Социалистическое землеустройство. № 5.

Платунов Н.И. (1976). Переселенческая политика советского государства и ее осуществление в СССР (1917- июнь 1941 гг.). Томск.

Попов Ф. (1929). Задачи и перспективы переселения в СССР // Вестник землеустройства и переселения. № 9.

Постановление VIII Всеукраинского съезда Советов по докладу «О землеустройстве» (1924) // Землеустройство. Сб-к руководящих статей и действующих правительственных распоряжений по вопросам землеустройства / Под ред. В.С. Березикова, М.М. Бицилли, Н.К. Мартыновского. Одесса.

Проект правил об условиях и порядке переселения на земли колонизационного фонда УССР (1924) // Землеустройство. Сб-к руководящих статей и действующих правительственных распоряжений по вопросам землеустройства / Под ред. В.С. Березикова, М.М. Бицилли, Н.К. Мартыновского. Одесса.

Резолюции Всероссийского земельного съезда 2-7 декабря 1921 (1921). М.: Изд. НКЗ.

Рубинский В. (1927). Переселенческое дело в Сибири и на Дальнем Востоке // Вестник землеустройства и переселения. № 3.

Рудин Н.П. (1930). Госземколонит должен быть сохранен // Социалистическое землеустройство. № 5.

Садвокасов С. (1928). О национальностях и националах // Большевик. № 1.

Сахаров А.М. (1927а). Пленум ВПК от 5-6 июня // Вестник землеустройства и переселения. № 1.

Сахаров А.М. (1927b). В Президиуме Всесоюзного Переселенческого Комитета // Вестник землеустройства и переселения. № 3.

Сахаров А.М. (1928а). Перспективный пятилетний план переселения на земельные фонды общесоюзного значения // Вестник землеустройства и переселения. № 5. 
Сахаров А.М. (1928b). Переселенческий план на земельные фонды союзного значения // Вестник землеустройства и переселения. № 5.

Сахаров А.М. (1928c). Директивы СНК СССР и Президиума ВПК по переселению // Вестник землеустройства и переселения. № 7.

Седельников Т. (1907). Борьба за землю в киргизской степи (Киргизский земельный вопрос и колонизационная политика правительства). СПб.

Сельскохозяйственная жизнь (1921). № 6

Серов М. (1926). Землеустройство в южных губерниях Казахстана и Киргизской автономной области (По материалам Особой комиссии ВЦИК по землеустройству) // Власть Советов. № 29-20.

Серяков П.А. (1924). Переселенческий вопрос в Одесской губернии // Землеустройство. Сб-к руководящих статей и действующих правительственных распоряжений по вопросам землеустройства / Под ред. В.С. Березикова, М.М. Бицилли, Н.К. Мартыновского. Одесса.

С3 СССР (1925a). № 21, ст. 136.

С3 СССР (1925b). № 30, ст. 193.

Симонов М. (1917). О направлении колонизационной деятельности в ближайшем будущем // Вопросы колонизации. Период. сб-к. № 20. Пг.

Сластухин Ф. (1930). Учет миграционных процессов в районах сплошной коллективизации // Социалистическое землеустройство. № I - II.

Смирнов А.П. (1926). Итоги III-его совещания наркомов земледелия // Сельскохозяйственная жизнь. № 50.

Соколов А.К. (2001). Историческое значение НЭПа // НЭП в контексте исторического развития России XX века. М.

Среднеазиатский экономический район. Очерки по экономике Средней Азии (1922) / Под ред. и с введен. Ю.И. Пославского и Г.Н. Черданцева, с предисл. Н.А. Паскуцкого. Ташкент.

СУ РСФСР (1918). № 325, ст. 346.

СУ РСФСР (1919). № 24, ст. 278.

СУ РСФСР (1921). № 159, ст. 396.

СУ РСФСР (1922а). № 11, ст. 106.

СУ РСФСР (1922b). № 34, ст. 401.

СУ РСФСР (1922c). № 68, ст. 901.

СУ РСФСР (1924а). № 68, ст. 679.

СУ РСФСР (1924b). № 68, ст. 681.

СУ РСФСР (1925а). № 3, ст. 17.

СУ РСФСР (1925b). № 49, ст. 371.

СУ РСФСР (1925с). № 57, ст. 453.

СУ РСФСР (1926). № 4, ст. 23.

СУ СССР (1924). № 23, ст. 201. 
СУ СССР. № 8, ст.63 (1928) // Известия ЦИК. № 27.

Трайнин И. (1923). К постановке национального вопроса // Власть Советов. № 5.

Тресвятский В.А. (1917). Материалы по земельному вопросу в Азиатской России. Вып.1. Степной Край / Под ред. Г.Ф. Чиркина и Л.К. Чермака. Пг.

Третий съезд Советов Союза Советских Социалистических Республик (1925). М.

Турчанинов Н. (1926). Потребность в миграциях сельского населения в связи с его дифференциацией в Центрально-Земледельческом, Западном, ЦентральноПромышленном и Северо-Западном районах // Труды Научно-исследовательского колонизационного института. Т.III. Материалы по вопросу об избыточном труде в сельском хозяйстве СССР / Под ред. Л.И. Лубны-Герцыка. М.

Циркуляр НКЗ РСФСР от 04.01.1926. Об открытии ходачества в 1926 г. (1927) // Переселенческое дело. Сборник декретов и распоряжений по переселению / Под ред. и с предисл. М.А. Большакова. М.

Чешихин Г.В. (1930). «Колонизациеведение» проф. В.П. Вощинина // Социалистическое землеустройство. № 7-8.

Шулейкин И. (1930). Переселение - на новые рельсы // Социалистическое землеустройство. № 3-4.

Юрцовский Н. (1928). Статистико-экономические работы переселенческой организации. Вопросы переселения и колонизации // Земледельческий работник Сибири. № 3-5. Новосибирск.

Ядринцев Н.М. (1892). Сибирь как колония в географическом, этнографическом и историческом отношении. 2-ое изд., испр. и доп. СПб.

Ямзин И.Л, В.П. Вощинин (1926). Учение о колонизации и переселениях. М.-Л.

Ямзин И.Л. (1912). Переселенческое движение в России с момента освобождения крестьян. Киев.

Ямзин И.Л. (1924). О постановке колонизационных и миграционных проблем в России // Труды Государственного колонизационного института. Т. І. М.

Ямзин И.Л. (1927). Переселенческая проблема в условиях текущего момента // Вестник землеустройства и переселения. № 1.

Ямзин И.Л. (1928). К вопросу о планировании в переселенческом деле // Вестник землеустройства и переселения. № 9. 


\section{PEASANT RESETTLEMENT IN THE 1920S (FROM THE HISTORY OF MIGRATION IN RUSSIA)}

\section{VALENTINA MOISSEENKO}

Valentina M. Moiseenko. Lomonosov Moscow State University, Russia.

E-MAIL:Vmoiseenko.msu@mail.ru.

DATA RECEIVED: MARCH 2015

The transformation of migration after October 1917 due to the inevitable radical reconstruction of the political and socio-economic system of society resulted in a change of its basic features. The theoretical basis of this transformation was laid during the years of military communism and was in much in demand at the end of the 1920s.

Due to objective and subjective reasons, the transformation could not affect the migration of peasants to areas rich in agricultural land, which was closely linked to the stage of pre-war resettlement and colonization, and remained one of the central problems in the 1920s. The features of the regulation of these processes (the late start of planned resettlement in 1924-1925s and the end of resettlement of individual farms in 1930s, the abolition of the term "colonization") influenced the attitude towards processes that played an important role in the history of Russia. But the short period of resettlement and colonization in the 1920s was preceded by a period full of movements of peasants to the Asian part of Russia and of discussion of the prospects of this process. Therefore, it was impossible to ignore the pre-war trends and implications of relocation in the 1920s, as well as the great experience - informational, legislative and organizational - of resettlement. The "conductors" of such experience were scientists and experts. Some of them worked at the former Resettlement Department. However, an attempt to revive the resettlement plans contradicted the plans of the state. In the late 1920s, the state of resettlement was assessed as critical. At the same time, studies of colonization and migration were stopped.

In fact, resettlement of peasants from the 1880s until the end of the 1920s was a single process. This circumstance determined the structure of the article. At the same time the least studied is the last stage resettlement in the 1920s.

Key words: transformation of migration, resettlement, agrarian overpopulation, colonization, resettlement case, resettlement statistics, the composition of immigrants, planned resettlement, immigration policy, effectiveness of the resettlement, Russia.

\section{REFERENCES}

Barov A. (1928). Pereseleniye na novyye zemli [Resettlement to the new lands]. MoscowLeningrad. $2^{\text {nd }}$ ed.

Barov A. (1929). Kuda i kak pereselyat'sya [Where and how to resettle]. Moscow.

Belevskiy A.A. (1904). K pereselencheskomu voprosu [Towards a resettlement question] // Russkoye bogatstvo [Russian wealth]. № 1.

Berkengeym A.M. (1902). Pereselencheskoye delo v Sibiri (Po lichnym nablyudeniyam i ofitsial'nym dannym) [Resettlement practice in Siberia (Based on personal observations and official data)]. Moscow.

Bol'shakov M. (1923). Zadachi i perspektivy kolonizatsii [Problems and prospects of colonization]// Na novykh putyakh. Itogi ekonomicheskoy politiki 1921-1922 g. [On the new ways. The results of the economic policy of the 1921-1922s]. 5(1). Sel'skoye khozyaystvo [Agriculture]. Moscow.

Bol'shakov M. (1924). K planu kolonizatsionno-pereselencheskikh meropriyatiy na 1923/24 g. [Towards the plan of colonization and resettlement activities for the 1923-24s] // Trudy 
Gosudarstvennogo kolonizatsionnogo nauchno-issledovatel'skogo institute [Proceedings of the National Colonization Research Institute]. T.1. Moscow.

Bol'shakov M. (1926). Polozheniye pereselencheskogo dela v SSSR [Provision of resettlement in the USSR] // Sel'skokhozyaystvennaya zhizn' [Agricultural life]. 49.

Bol'shakov M. (1928). Dal'nevostochnoye i sibirskoye pereseleniye (Po materialam obsledovaniya Narkomzema RSFSR) [Far Eastern and Siberian resettlement (According to the People's Commissariat of the RSFSR survey)] // Vestnik zemleustroystva i pereseleniya [Annals of Land Planning and Resettlement]. 4.

Cheshikhin G.V. (1930). «Kolonizatsiyevedeniye» prof. V.P. Voshchinina [Studies of colonization by prof. V.P. Voshchinina ] // Sotsialisticheskoye zemleustroystvo [Social Land Planning]. 7-8.

Dan'shin A.I., M.M. Lobanov (2008). Kazakhstan / Bol'shaya Rossiyskaya entsiklopediya [Big Russian Encyclopedia]. T. 12. Moscow.

Desyatyy s"yezd RKP(b) [The tenth forum of the Communist Party of the Soviet Union]. Mart 1921 g. Stenograficheskiy otchet [Transcript] (1962). Moscow.

Dvizheniye v Sibkray pereselentsev-samovol'tsev [Traffic of settlers to Siberia] (1928) // Vestnik zemleustroystva i pereseleniya [Annals of Land Planning and Resettlement]. 6.

Govberg G. (1929). Pereseleniye i yego vliyaniye na narodnoye khozyaystvo [Resettlement and its impact on the national economy] // // Vestnik zemleustroystva i pereseleniya [Annals of Land Planning and Resettlement]. № 6.

Izvestiya TSIK (1928b) [Proceedings of the Central Election Commission]. 89.

Izvestiya TSIK (1928c) [Proceedings of the Central Election Commission]. 94.

Izvestiya TSIK [Proceedings of the Central Election Commission] (1928a). 22.

Izvlecheniye iz rezolyutsii 2-go Vserossiyskogo soveshchaniya zemel'nykh rabotnikov. 2-8 marta 1924 goda. Pereseleniye [Extract from the resolution of the 2nd National Conference of the land workers. March 2-8, 1924. Resettlement] (1927) // Pereselencheskoye delo. Sbornik dekretov i rasporyazheniy po pereseleniyu [Resettlement deal. Collection of decrees and orders of the resettlement] / M.A. Bol'shakova, ed. and foreword.

K soveshchaniyu gubernskikh zemel'nykh upravleniy. Tezisy dokladov upravleniy i khozorganov NKZ (1924) [For the meeting of the provincial land offices. Abstracts offices and hozorganov CGN]. Moscow.

Kaufman A.A. (1915a). Pereseleniya i pereselencheskiy vopros v Rossii [Resettlement and resettlement question in Russia] // Entsiklopedicheskiy slovar' Russkogo Bibliograficheskogo instituta. Sed'moye izdaniye [Russian Encyclopedic Dictionary of the Bibliographical Institute. The seventh edition]. T.31. Moscow: Granat.

Kaufman A.A. (1915b). Pereselencheskaya statistika (razdel'naya poginatsiya) [Resettlement statistics (separate pagination)] // Entsiklopedicheskiy slovar' Russkogo Bibliograficheskogo instituta. Sed'moye izdaniye [Russian Encyclopedic Dictionary of the Bibliographical Institute. The seventh edition]. T.31. Moscow: Granat.

Kaufman A.A. (1918). Pereseleniye i yego vozmozhnaya rol' v zemel'noy reforme [Resettlement and its possible role in the land reform] // Otd. ott. stat'i iz zhurnala «Sel'skoye khozyaystvo i lesovodstvo» [Agriculture and forestry]. T. 256. Petrograd. 
Kenarskiy L. (1924). Kolonizatsiya i pereseleniya v Kirgizskiy kray (Istoricheskaya spravka) [The colonization and resettlement in Kyrgyz territory (History)] // Sovetskaya Kirgiziya [Soviet Kyrgyzstan]. 11-12.

Kosmachevskiy K.V. (1928). Pyatiletniy plan deyatel'nosti Gosudarstvennogo NII zemleustroystva i pereseleniya [The five-year plan of the State Research Institute of Land Planning and Resettlement] // Vestnik zemleustroystva i pereseleniya [Annals of Land Planning and Resettlement]. 4.

Krasil'nikov M. (1928). Sostav pereselentsev [Resettles`structure] // Statisticheskoye obozreniye [Statistical Review]. 12.

Krasil'nikov M. (1930). Agrarnoye pereseleniye v 1928/29 g. [The agrarian resettlement in 1928/29] // Statisticheskoye obozreniye [Statistical Review]. 5.

Krasil'nikov M.P. (1929). K postanovke pereselencheskoy statistiki [Towards resettlement statistics] // Vestnik statistiki [Annals of Statistics]. 2.

Latsis M.I. (1927). Tekushchiye voprosy pereselencheskogo dela [Current issues of resettlement cases] // Vestnik zemleustroystva i pereseleniya [Annals of Land Planning and Resettlement]. 1.

Latsis M.I. (1928). O kolkhoznom i sovkhoznom stroitel'stve v rayonakh zaseleniya [On the collective and state building in the areas of settlement] // Vestnik zemleustroystva i pereseleniya [Annals of Land Planning and Resettlement]. 5.

Lenskiy N. (1914). Samovol'nyye pereselentsy i pereselencheskoye zakonodatel'stvo [Voluntary settlers and the resettlement legislation] // Voprosy kolonizatsii [Annals of colonization] / G.F. Chirkina i N.A. Gavrilova, eds. 14. St. Petersburg.

Lyaskovskiy G. (1929). Predvaritel'nyye itogi pereseleniya za 1928 g. i oriyentirovochnyye kontrol'nyye tsifry na $1929 \mathrm{~g}$. [Preliminary results of resettlement in 1928 and indicative target figures for 1929] // Vestnik zemleustroystva i pereseleniya [Annals of Land Planning and Resettlement]. 1.

M.TS. [Retsenziya, Review] (1930). Ucheniye o kolonizatsii i pereseleniyakh [The doctrine of colonization and resettlement] // Na agrarnom fronte [On the agricultural front]. 2.

Mebus G.A., V.P. Voshchinin (1926). Zadachi sektsii prikladnoy geografii [Tasks of the section on Applied Geography] // Sbornik geografo-ekonomicheskogo instituta (pri geograficheskom fakul'tete LGU) za $1926 \mathrm{~g}$. [Collection of the geographical and economic institute (at the Leningrad State University, Faculty of Geography) of 1926] / N.I. Kuznetsova i S.A. Sovetova, eds. Leningrad.

Nebol'sin A.N. (1928). Pereselencheskoye dvizheniye krest'yan iz Voronezhskoy gubernii [Resettlement movement of peasants from the Voronezh province] / A.N. Tatarchuka, ed. and forward. Voronezh.

Novitskiy I.B. (1928). Zakon i praktika zemleustroystva i pereseleniya (15 yanvarya -20fevralya 1928 goda) [The law and practice of land planning and resettlement (15 January -20fevralya 1928)] // Vestnik zemleustroystva i pereseleniya [Annals of Land Planning and Resettlement]. 5.

O zapreshchenii pereseleniya v KSSR iz-za predelov yeye, samovol'nogo pereseleniya vnutri yeye i o meropriyatiyakh $\mathrm{v}$ otnoshenii zemel'nogo ustroystva uzhe pereselivshikhsya [About the prohibition of resettlement to KSSR from the outside, voluntary relocation inside it and on the activities of land planning for the already resettled] (1925). Orenburg. 
Oganovskiy N.P. (1917). Problema pereraspredeleniya zemel'nogo fonda i yeye rol' v sovremennoy agrarnoy reforme [The problem of the redistribution of the land fund and its role in the modern agrarian reform] // Osnovnyye voprosy agrarnoy reformy na 2-om Vserossiyskom s"yezde Ligi agrarnykh reform [The main issues of agrarian reform at the 2nd All-Russian Congress of the League of Agrarian Reform]. Seriya A. № 2. Moscow.

Oganovskiy N.P. (1921). Narodnoye khozyaystvo Sibiri. Epizodicheskiy kurs lektsiy, prochitannykh na kooperativnykh kursakh dlya slushateley i rabochikh kooperativnykh organizatsiy gor. Omska v fevrale-marte 1920-g goda. S 12-yu diagrammami i kartogrammami [The national economy of Siberia. The episodic course of lectures delivered on cooperative courses for the students and workers of co-operative organizations in Omsk in February-March 1920 with 12th diagrams and cartograms]. Omsk.

Oganovskiy. N.P. (1914). Zakonomernost' agrarnoy evolyutsii [The patterns of agrarian evolution]. T. III. Obnovleniye zemledel'cheskoy Rossii i agrarnaya politika [The update of the Russian agricultural and agrarian policy]. Vyp. I. Naseleniye. Pereselencheskiy vopros. Saratov.

Osnovnoy Zakon (Konstitutsiya) Soyuza Sovetskikh Sotsialisticheskikh respublik (Utverzhden II S"yezdom Sovetov Soyuza SSSR) [The Basic Law (Constitution) of the Union of Soviet Socialist Republics (Approved by the II Congress of Soviets of the USSR Union)] (1940) // Konstitutsii i konstitutsionnyye akty Soyuza SSSR (1922-1936) [he Constitution and constitutional acts of the Soviet Union (1922-1936)]. Sbornik dokumentov [Collection of the documents] / I.P. Traynina, ed. Moscow.

Osnovnyye zadachi Vsesoyuznogo pereselencheskogo soveshchaniya pri Pereselencheskom komitete TSIKa Soyuza SSR [The main objectives of All-union the Resettlement Meeting by the Resettlement Committee of the Central Executive Committee of the USSR] (1929) // Vestnik zemleustroystva i pereseleniya [Annals of Land Planning and Resettlement]. 9.

Pereselencheskoye delo [Resettlement Activities] (1927) // Sbornik dekretov i rasporyazheniy po pereseleniyu [Collection of decrees and orders of the resettlement] / M.A. Bol'shakova, ed. and foreword. Moscow.

Pereselencheskoye delo na novykh putyakh [Resettlement activities under new conditions] (1930) // Sotsialisticheskoye zemleustroystvo [Social land planning]. № 5.

Platunov N.I. (1976). Pereselencheskaya politika sovetskogo gosudarstva i yeye osushchestvleniye v SSSR (1917- iyun' 1941 gg.) [Resettlement policy of the Soviet state and its implementation in the USSR (1917 and June, 1941.)]. Tomsk.

Popov F. (1929). Zadachi i perspektivy pereseleniya v SSSR [Tasks and prospects of resettlement in the USSR] // Vestnik zemleustroystva i pereseleniya [Annals of Land Planning and Resettlement]. 9.

Postanovleniye VIII Vseukrainskogo s"yezda Sovetov po dokladu «O zemleustroystve» [Decision of the VIII All-Ukrainian Congress of Soviets on the report "On Land Planning"] (1924) // Zemleustroystvo. Sb-k rukovodyashchikh statey i deystvuyushchikh pravitel'stvennykh rasporyazheniy po voprosam zemleustroystva [Land Planninfg. Collection of the articles and guidelines of existing government regulations on land planning] / V.S.

Berezikova, M.M. Bitsilli, N.K. Martynovskogo, eds. Odessa.

Proyekt pravil ob usloviyakh i poryadke pereseleniya na zemli kolonizatsionnogo fonda USSR [Draft of rules on the conditions and procedure for the relocation to the land colonization fund of the Ukrainian SSR] (1924) // Zemleustroystvo. Sb-k rukovodyashchikh statey i deystvuyushchikh pravitel'stvennykh rasporyazheniy po voprosam zemleustroystva [Land 
Planning. Collection of the articles and guidelines of existing government regulations on land planning] / V.S. Berezikova, M.M. Bitsilli, N.K. Martynovskogo, eds. Odessa.

Rezolyutsii Vserossiyskogo zemel'nogo s"yezda 2-7 dekabrya 1921 [Resolution of All-Russian Land Congress, December 2-7, 1921] (1921). M.: Izd. NKZ.

Rubinskiy V. (1927). Pereselencheskoye delo v Sibiri i na Dal'nem Vostoke [Resettlement activities in Siberia and the Far East] // Vestnik zemleustroystva i pereseleniya. № 3.

Rudin N.P. (1930). Goszemkolonit dolzhen byt' sokhranen [Goszemkolonit must be saved] // Sotsialisticheskoye zemleustroystvo [Socialist Land Planning]. 5.

Sadvokasov S. (1928). O natsional'nostyakh i natsionalakh [On the Nationalities and Nationals] // Bol'shevik. 1.

Sakharov A.M. (1927a). Plenum VPK ot 5-6 iyunya [Plenum of the MIC, June 5-6] // Vestnik zemleustroystva i pereseleniya [Annals of Land Planning and Resettlement]. 1.

Sakharov A.M. (1927b). V Prezidiume Vsesoyuznogo Pereselencheskogo Komiteta [In the Presidium of the Union Resettlement Committee] // Vestnik zemleustroystva i pereseleniya [Annals of Land Planning and Resettlement]. 3.

Sakharov A.M. (1928a). Perspektivnyy pyatiletniy plan pereseleniya na zemel'nyye fondy obshchesoyuznogo znacheniya [Prospective five-year plan for the resettlement within the land fund of national importance] // Vestnik zemleustroystva i pereseleniya [Annals of Land Planning and Resettlement]. 5.

Sakharov A.M. (1928b). Pereselencheskiy plan na zemel'nyye fondy soyuznogo znacheniya [Resettlement plan for the land fund of national importance] // Vestnik zemleustroystva i pereseleniya [Annals of Land Planning and Resettlement]. 5.

Sakharov A.M. (1928c). Direktivy SNK SSSR i Prezidiuma VPK po pereseleniyu [Directives of SNK USSR and MIC Presidium on resettlement] // Vestnik zemleustroystva i pereseleniya [Annals of Land Planning and Resettlement]. 7.

Sedel'nikov T. (1907). Bor'ba za zemlyu v kirgizskoy stepi (Kirgizskiy zemel'nyy vopros i kolonizatsionnaya politika pravitel'stva) [The struggle for the land in the Kirghiz steppes (Kirgiz land issue and the colonization policy of the government)]. St. Petersburg.

Sel'skokhozyaystvennaya zhizn' [Agricultural Life] (1921). № 6

Serov M. (1926). Zemleustroystvo v yuzhnykh guberniyakh Kazakhstana i Kirgizskoy avtonomnoy oblasti (Po materialam Osoboy komissii VTSIK po zemleustroystvu) [Land planning in the southern provinces of Kazakhstan and the Kyrgyz autonomous region (According to the Special Commission of the Central Executive Committee on Land Planning)] // Vlast' Sovetov [Soviet power]. 29-20.

Seryakov P.A. (1924). Pereselencheskiy vopros v Odesskoy gubernii [Resettlement issue in the Odessa province] // Zemleustroystvo. Sb-k rukovodyashchikh statey i deystvuyushchikh pravitel'stvennykh rasporyazheniy po voprosam zemleustroystva [Land Planning. Collection of the articles and guidelines of existing government regulations on land planning] / V.S. Berezikova, M.M. Bitsilli, N.K. Martynovskogo, eds. Odessa.

Shuleykin I. (1930). Pereseleniye - na novyye rel'sy [Relocation - a new track] // Sotsialisticheskoye zemleustroystvo. № 3-4.

Simonov M. (1917). O napravlenii kolonizatsionnoy deyatel'nosti v blizhayshem budushchem [On the direction of colonization activities in the near future] // Voprosy kolonizatsii [Annals of colonization]. Period. sb-k. № 20. Petrograd. 
Slastukhin F. (1930). Uchet migratsionnykh protsessov v rayonakh sploshnoy kollektivizatsii [Accounting for migration processes in the areas of complete collectivization] // Sotsialisticheskoye zemleustroystvo [Socialist Land Planning]. № I - II.

Smirnov A.P. (1926). Itogi III-yego soveshchaniya narkomov zemledeliya [The results of the III meeting of the Commissar of Agriculture // Sel'skokhozyaystvennaya zhizn' [Agricultural life]. № 50 .

Sokolov A.K. (2001). Istoricheskoye znacheniye NEPa [The historical significance of the NEP]// NEP v kontekste istoricheskogo razvitiya Rossii XX veka [NEP in the context of the historical development of Russia of the XX century]. Moscow.

Sredneaziatskiy ekonomicheskiy rayon. Ocherki po ekonomike Sredney Azii [Central Asian economic region. Essays on the Economics of Central Asia] (1922) / YU.I. Poslavskogo i G.N. Cherdantseva, N.A. Paskutskogo, eds. and foreword. Tashkent.

SU RSFSR [Codes of justice of RSSSR] (1919). № 24, page 278.

SU RSFSR [Codes of justice of RSSSR] (1921). № 159, page 396.

SU RSFSR [Codes of justice of RSSSR] (1922a). № 11, page 106.

SU RSFSR [Codes of justice of RSSSR] (1922b). № 34, page 401.

SU RSFSR [Codes of justice of RSSSR] (1922c). № 68, page 901.

SU RSFSR [Codes of justice of RSSSR] (1924a). № 68, page 679.

SU RSFSR [Codes of justice of RSSSR] (1924b). № 68, page 681.

SU RSFSR [Codes of justice of RSSSR] (1925a). № 3, page 17.

SU RSFSR [Codes of justice of RSSSR] (1925b). № 49, page 371.

SU RSFSR [Codes of justice of RSSSR] (1925c). № 57, page 453.

SU RSFSR [Codes of justice of RSSSR] (1926). № 4, page 23.

SU RSFSR[Codes of justice of RSSSR] (1918). № 325, page 346.

SU SSSR [Codes of justice of USSR] (1924). № 23, page 201.

SU SSSR [Codes of justice of USSR]. № 8, st.63 (1928) // Izvestiya TSIK. 27.

SZ SSSR [Collection of Laws of the USSR] (1925a). № 21, st. 136.

SZ SSSR [Collection of Laws of the USSR] (1925b). № 30, st. 193.

Traynin I. (1923). K postanovke natsional'nogo voprosa [For the national question] // Vlast' Sovetov [The power of the Soviets]. № 5 .

Tresvyatskiy V.A. (1917). Materialy po zemel'nomu voprosu v Aziatskoy Rossii [Materials on the land issue in the Asian part of Russia]. Vyp.1. Stepnoy Kray [Steppe Region] / G.F. Chirkina i L.K. Chermaka, eds. Petrograd.

Tretiy s"yezd Sovetov Soyuza Sovetskikh Sotsialisticheskikh Respublik [The Third Congress of Soviets of the Union of Soviet Socialist Republics] (1925). M.

Tsirkulyar NKZ RSFSR ot 04.01.1926. Ob otkrytii khodachestva v 1926 g. [Circular of CGN RSFSR ofrom 01.04.1926. On the opening of "hodachestva" in 1926] (1927) //

Pereselencheskoye delo. Sbornik dekretov i rasporyazheniy po pereseleniyu [Resettlement activities. Collection of the decrees and orders of the resettlement] / M.A. Bol'shakova, ed. and foreword. Moscow. 
Turchaninov N. (1926). Potrebnost' v migratsiyakh sel'skogo naseleniya v svyazi s yego differentsiatsiyey v Tsentral'no-Zemledel'cheskom, Zapadnom, Tsentral'no-Promyshlennom i Severo-Zapadnom rayonakh [The need for migration of the rural population due to its differentiation in the agricultural Central, West, Central Industrial and Northwest regions] // Trudy Nauchno-issledovatel'skogo kolonizatsionnogo instituta [Proceedings of the Research Institute of Colonization]. T.III. Materialy po voprosu ob izbytochnom trude v sel'skom khozyaystve SSSR [Materials on the question of excess labor in Soviet agriculture] / L.I. Lubny-Gertsyka, ed. Moscow.

Velikevich I. (1928a). Pereselencheskoye delo v SSSR, yego nedostatki i osnovnyye zadachi [Resettlement in the USSR, its shortcomings and basic tasks] // Vestnik zemleustroystva i pereseleniya [Annals of Land Planning and Resettlement]. 9.

Velikevich.I. (1928b). Pereselencheskoye dvizheniye krest'yan iz Voronezhskoy gubernii [Resettlement movement of peasants from the Voronezh province] // Vestnik zemleustroystva i pereseleniya [Annals of Land Planning and Resettlement].10.

Voshchinin V.P. (1912). Pereselencheskiy vopros v Gosudarstvennoy Dume III sozyva. Itogi i perspektivy [Resettlement question in the third convocation of the Duma. Results and prospects]. Moscow.

Voshchinin V.P. (1919). Gosudarstvennyye neotlozhnyye zadachi kolonizatsii [Public urgent tasks of colonization] // Ocherednyye voprosy kolonizatsii [Regular issues of colonization]. Vol. I. Sever Yevropeyskoy Rossii [North of European Russia] / V.P. Voshchinina, ed. Petrograd.

Voshchinin V.P. (1921). Pereseleniye [Resettlement] // O zemle [About the land]. Vol. 1. Sbornik statey o proshlom i budushchem zemel'no-khozyaystvennogo stroitel'stva [Collection of the articles about the past and the future of the land-economic development]. Moscow.

Voshchinin V.P. (1928). Raboty GEII v oblasti kolonizatsiyevedeniya (Po sektsii prikladnoy geografii) [GEII works on the colonization (Applied Geography section)] // Sbornik geografo-issledovatel'skogo instituta za $1927 \mathrm{~g}$ [Collection of The Geographical Research Institute of 1927] / N.I. Kuznetsova i S.A. Sovetova, eds. L.

Vsesoyuznaya perepis' naseleniya 1926 goda [All-Union population census in 1926] (1930a). T. 40. Moscow.

Vsesoyuznaya perepis' naseleniya 1926 goda [All-Union population census in 1926] (1930b). T.41. Moscow.

Vsesoyuznaya perepis' naseleniya 1926 goda [All-Union population census in 1926] (1930c). T. 42. Moscow.

Vsesoyuznaya perepis' naseleniya 1926 goda [All-Union population census in 1926] (1931). T. 51. Moscow.

Yadrintsev N.M. (1892). Sibir' kak koloniya v geograficheskom, etnograficheskom i istoricheskom otnoshenii [Siberia as a colony in the geographical, ethnographical and historical sence]. 2-oye izd., ispr. i dop. St. Petersburg.

Yamzin I.L, V.P. Voshchinin (1926). Ucheniye o kolonizatsii i pereseleniyakh [Theory of colonization and resettlement]. Moscow-Leningrad.

Yamzin I.L. (1912). Pereselencheskoye dvizheniye v Rossii s momenta osvobozhdeniya krest'yan [Resettlement movement in Russia since the liberation of the peasants]. Kiyev. 
Yamzin I.L. (1924). O postanovke kolonizatsionnykh i migratsionnykh problem v Rossii [On the formulation of colonization and migration problems in Russia] // Trudy Gosudarstvennogo kolonizatsionnogo instituta [Proceedings of the National Institute of Colonization]. T. I. Moscow.

Yamzin I.L. (1927). Pereselencheskaya problema v usloviyakh tekushchego momenta [Resettlement is a problem in terms of the moment] // Vestnik zemleustroystva i pereseleniya [Annals of Land Planning and Resettlement]. 1.

Yamzin I.L. (1928). K voprosu o planirovanii v pereselencheskom dele [On the issue of planning in resettlement activities] // Vestnik zemleustroystva i pereseleniya [Annals of Land Planning and Resettlement]. 9.

Yurtsovskiy N. (1928). Statistiko-ekonomicheskiye raboty pereselencheskoy organizatsii. Voprosy pereseleniya i kolonizatsii [Statistical and economic works of the resettlement organization. Resettlement and colonization] // Zemledel'cheskiy rabotnik Sibiri [Agrarian Worker of Siberia]. 3-5. Novosibirsk.

Zhdanov B.N. (1929). K voprosu ob effektivnosti zatrat na pereseleniye [On the question of costeffectiveness of the resettlement] // Vestnik zemleustroystva i pereseleniya [Annals of Land Planning and Resettlement]. 4.

Zhurnal zasedaniy Komissii po voprosam pereseleniya i kolonizatsii ot 22-go avgusta i 22-go sentyabrya 1917 goda [Journal of the Commission Conference on migration and colonization. Meetings of August 22 and September 22, 1917] (1917b) // Voprosy kolonizatsii. Period. Sbornik[Questions of colonization. Periodic collection]. 20. Petrograd.

Zhurnal zasedaniy Komissii po voprosam pereseleniya i kolonizatsii. Zasedaniye 7 avgusta 1917 g. [Journal of the Commission Conference on migration and colonization. Meeting of August 7, 1917] (1917a) // Voprosy kolonizatsii. Period. sbornik [Questions of colonization. Periodic collection] / G.F. Chirkina, ed. 20. Petrograd. 